\title{
Influence of particle type and faunal activity on mixing of di(2-ethylhexyl)phthalate (DEHP) in natural sediments
}

\author{
Joanna Sandnes ${ }^{1}$, Thomas Forbes ${ }^{2}$, Rikke Hansen ${ }^{3}$, Bjørnar Sandnes ${ }^{4, *}$ \\ ${ }^{1}$ Norwegian Institute for Water Research (NIVA), PO Box 173 Kjelsås, 0411 Oslo, Norway \\ ${ }^{2}$ Department of Marine Ecology, National Environmental Research Institute, PO Box 358, Frederiksborgvej 399, \\ 4000 Roskilde, Denmark \\ ${ }^{3}$ Darling Marine Center, University of Maine, Walpole, Maine 04573, USA \\ ${ }^{4}$ Department of Physics, University of Oslo, PO Box 1048 Blindern, 0316 Oslo, Norway
}

\begin{abstract}
The influence of faunal activity and particle type on sediment-mixing processes of the particle-bound, organic contaminant di(2-ethylhexyl) phthalate (DEHP) were examined over a 48 d experimental period with natural box-cosm sediments. A dual-labelling radiotracer technique using ${ }^{14} \mathrm{C}$ DEHP and ${ }^{51} \mathrm{Cr}$ determined the fate and utilization of DEHP associated with either sediment or phytoplankton particles. Particle-mixing was estimated using a 1-dimensional transient-state biodiffusion model and expressed as $D_{\mathrm{b}}$ coefficients. Sediment ${ }^{51} \mathrm{Cr}$ depth profiles fitted this simple biodiffusion model well, indicating randomized, vertical particle mixing. Particle reworking rates were approximately 9 -fold higher in faunated treatments compared to defaunated control sediments, thus quantifying the importance of benthic fauna as agents of physical transport. Biodiffusion rates in faunated boxcosms were significantly higher in phytoplankton compared to sediment ${ }^{14} \mathrm{C}$-DEHP particle treatments $(p<0.05)$. This was attributed to an experimental urchin effect resulting from natural variations in the density of the large macrofaunal urchin Echinocardium cordatum between particle treatments. Sediment-mixing rates were independent of particle type when this urchin effect was removed. Examination of ${ }^{14} \mathrm{C}$ and ${ }^{51} \mathrm{Cr}$ relative depth profiles showed the 2 tracers to be coupled in defaunated sediments and decoupled with animals present. This effect was also independent of particle-type, indicating no selective transport associated with the particle-type treatments. The decoupling of tracers in faunated treatments, with ${ }^{14} \mathrm{C}$-DEHP having consistently higher depth-weighted mean values than the ${ }^{51} \mathrm{Cr}$ tracer, suggested a decrease in surface ${ }^{14} \mathrm{C}$-DEHP concentrations through degradation processes at the sediment-water interface. Sediment-mixing rates increased significantly with increasing total community biomass, indicating that size (biomass) may be the single most important community parameter determining sediment-mixing intensity. Downward particle transport was strongly correlated with $E$. cordatum abundance $(\mathrm{p}<0.01)$, the dominant species in the benthic community in terms of size. E. cordatum densities also correlated strongly with the number of benthic infaunal species present in the box-cosms, with maximum infaunal species numbers occurring at intermediate $E$. cordata densities. This is in accordance with theories on intermediate disturbance. The $2{ }^{14} \mathrm{C}$-DEHP particle-type treatments had no significant effect on $E$. cordata body sizes or DEHP body burden. The large urchin $E$. cordatum clearly dominated sediment-mixing, and did so in a 'non-selective' manner.
\end{abstract}

KEY WORDS: Bioturbation · Organic contaminants $\cdot$ Phthalate $\cdot$ Sediment $\cdot$ Tracers $\cdot$ Particle quality Selective transport - Echinocardium cordatum - Disturbance

\section{INTRODUCTION}

Sediment-mixing, or bioturbation, by benthic infauna has profound effects on the physical and geochemical

•Corresponding author. E-mail: bsand@fys.uio.no properties of sediments. Bioturbation arises from the feeding, burrowing and general faunal locomotory activities of the resident deposit-feeding community (Berner 1980, Gerino et al. 1998). By altering the sediment fabric, bioturbation affects a wide range of sedimentary phenomena. Rates of organic matter and con- 
taminant degradation, the dissolution of various biogenic components $\left(\mathrm{CaCO}_{3}\right.$ and $\left.\mathrm{SiO}_{2}\right)$, microbial activity, and pore-water-concentration profiles of nearly all dissolved chemical species are affected by the intensity of bioturbation (Berner 1980, Wheatcroft et al. 1990, Gerino et al. 1998, Soetaert et al. 1998).

The mechanisms and rates of sediment particlemixing are typically estimated by changes in depth profiles of either naturally occurring, particle-reactive radionuclides (Boudreau 1986), or by inert particles naturally or artificially introduced as tracers; these include isotopically labelled particles, glass beads, fluorescent particles and metal-doped sediment (Wheatcroft 1992, Wheatcroft et al. 1994, Madsen et al. 1997, Gerino et al. 1998, Hansen et al. 1999). The mixing of such tracers is typically modelled quantitatively as a 1dimensional (vertically) diffusive process and a biodiffusion coefficient $\left(D_{\mathrm{b}}\right)$ is estimated, analogous to a standard Fickian diffusivity (Berner 1980, Smith et al. 1993, Gerino et al. 1998). Such biodiffusion rates $\left(D_{\mathrm{b}} \mathrm{s}\right)$ incorporate all animal activities affecting the sediment (e.g. deposit-feeding, burrows, tube-building) into a single coefficient (Wheatcroft et al. 1990, Sandnes et al. 2000 [in this issue]).

Sediment-mixing intensity has been shown to be primarily controlled by the deposit-feeding activities of the mega- and macrobenthos (Thayer 1983, Wheatcroft et al. 1990). Deposit-feeding, in turn, is known to be extremely complex, depending on particulate shape (Whitlatch 1974), size (Powell 1977, Wheatcroft \& Jumars 1987, Wheatcroft 1992) and organic content (Cammen 1989, Rice \& Rhoads 1989, Smith et al. 1993). Particulate organic content is also a factor directly correlated with the sorption of organic contaminants to particles (Al-Oman \& Preston 1987, de Witt et al. 1992, Williams et al. 1995). An understanding of the transport of different particle types is therefore critical to determine the fate and bioavailability of these associated contaminants (Landrum \& Robbins 1990, Harkey et al. 1994, Maloney 1996).

One well-documented experimental method for estimating particle selection by deposit feeders is a duallabelling ${ }^{14} \mathrm{C} /{ }^{51} \mathrm{Cr}$ technique that measures the absorption of an ingested ${ }^{14} \mathrm{C}$ compound by the change in ${ }^{14} \mathrm{C} /{ }^{51} \mathrm{Cr}$ ratio. This method has been used for many years to measure ingestion and absorption of different food sources in controlled microcosm studies (Calow \& Fletcher 1972, Kofoed 1989, Lopez \& Elmgren 1989). The new application of this technique to contaminated sedimentary deposits allows bulk particle transport and ingestion processes to be determined (Hansen et al. 1999).

Many coastal and estuarine sediments contain high concentrations of anthropogenically derived contaminants. Models that assess the influence of bioturbation on particle-sorbed pollutant diagenesis predict that areas of high bioturbation will tend to accumulate pollutants by trapping bedload and horizontally transported material (Aller 1982). In this way, sedimentdwelling infauna may increase their exposure to sediment-associated pollutants through their own bioturbatory activities and thus create a negative feedback loop between pollutant fate and effect (Forbes \& Forbes 1994). Another potentially important effect of bioturbation is, however, to stimulate the microbial degradation of sediment contaminants, resulting in a positive feedback effect (Bauer et al. 1988, Hansen et al. 1999). Therefore, through bioturbation, benthic fauna have great potential to indrectly control the fate and subsequent bioavailability of sedimentary contaminants in their immediate environment (Madsen et al. 1997).

Phthalate esters have become one of the most prevalent classes of chemicals in industry today. Used primarily as softners in plastics, especially PVC products, but also in industrial paints, adhesives, varnishes, cosmetics, lubricants and as pesticide carriers, phthalates (especially di(2-ethylhexyl)phthalate [DEHP]) have become ubiquitous environmental pollutants (Wams 1987). Phthalates are weakly oestrogenic and lipophilic in nature (Jobling et al. 1995), and are thought to accumulate in aquatic organisms at low environmental levels, disturbing processes related to reproduction and growth (Kohli et al, 1989). Their characteristic hydrophobic properties make them highly insoluble in water, with a tendency to associate with organic material (Karickoff \& Morris 1985). Thus, sediments are the ultimate sinks for such environmental contaminants.

Once bound in the sediment, the release of phthalates into the pelagic ecosystem is controlled by desorption processes, particulate resuspension, and biologically mediated transport, i.e. bioturbation and bioaccumulation in infaunal organisms. Bioturbation may therefore play a key role in redistributing adsorbed contaminants within the sediment, altering chemical binding and Gerino 1992, adsorption/desorption processes, and Gerino 1992, influencing fluxes to and from the overlying water, and may enhance microbial degradation of compounds (Aller 1982, Bauer et al. 1988, Hansen et al. 1999). As a result, the bioavailability of such contaminants is significantly affected by sediment-mixing activities.

This study focused on the association of phthalates, specifically DEHP, with different types of particles (natural sediment particles, and cultured phytoplankton cells) and subsequent sediment transport. These 2 particle types vary in potential food value to the benthos, with phytoplankton being considered as 'food-rich' compared to sediment particles. Primary production by phytoplankton in surface waters is a 
major source of labile organic carbon for coastal sediments (Sun et al. 1991). In this study, the sedimentation of phytoplankton to the sediment-water interface during a spring bloom period was simulated by the addition of appropriate levels of cultured phytoplankton.

Treatments were added as a pulse input to natural sub-tidal box-cosm sediment to determine if the association of DEHP with different particle types affected the distribution and fate of DEHP in sub-tidal sediments. Sediment-mixing processes were quantified as $D_{b} s$, and the selective transport of particles was investigated using the dual-labelling ${ }^{14} \mathrm{C} /{ }^{51} \mathrm{Cr}$ technique applied for the first time to natural sediments. This experimentation with natural sediments maintained both the infaunal community and micromorphological sedimentary structures.

\section{MATERIALS AND METHODS}

Experimental box-cosm system. The experimental box-cosm system consisted of 12 PVC box-cores $\left(0.25 \mathrm{~m}^{2}\right)$ of natural sediment collected in the Oslofjord at Håøytangen $\left(59^{\circ} 40^{\prime} \mathrm{N}, 10^{\circ} 36^{\prime} \mathrm{E}\right)$, from a depth of 60 to $62 \mathrm{~m}$ in July 1996. A flow-through water system with a header tank supplied unfiltered seawater continuously at a constant rate of approximately $0.5 \mathrm{I} \mathrm{\textrm {min } ^ { - 1 }}$ from $60 \mathrm{~m}$ depth at Solbergstrand, Oslofjord. A constant seawater temperature and a constant salinity of $8.8( \pm 0.4)^{\circ} \mathrm{C}$ and $34.5( \pm 0.3) \%$, respectively, were recorded automatically for the duration of the experiment. The surface sediment contained $5.48( \pm 0.3) \%$ carbon after removal of carbonates by acid-fuming (Hedges \& Stern 1984), and nitrogen content was 0.71 $( \pm 0.1) \%$ (Perkin Elmer CHN-analyser, Model 240C); hence the $C: N$ ratio was 7.72 . The box-cosms were allowed to acclimatize with the flow-through seawater system for $20 \mathrm{~d}$ prior to treatment.

Experimental design. The association of the organic contaminant, DEHP to different particle types in faunated and defaunated sediments represented the experimental treatments and controls respectively. Two particle types were used: surface sediment particles and phytoplankton cells. The surface sediment was collected from the same site as the box cores, and hence contained the same $\mathrm{C}$ and $\mathrm{N}$ content. Rhodomonas baltica was the selected flagellate species cultured for the phytoplankton treatment. $R$. baltica is a common bloom species in northern European seas, and is a preferred species in feeding studies because of its high nutritional value (Riisgård 1991, Jónasdóttir 1994).

The phytoplankton was cultured until late-log phase in $0.2 \mu \mathrm{m}$ sterile-filtered, 35\% surface seawater, en- riched with a standard culture medium Z8 (NIVA) and vitamins: $10 \mathrm{mg}$ thiamine, $0.1 \mathrm{mg}$ biotin and $0.1 \mathrm{mg} \mathrm{B}_{12}$. The total cell number of $7.5 \times 10^{11}$ contributed $\sim 2.34 \mathrm{~g}$ $C$ to each box-cosm, representing a total enrichment of $9.37 \mathrm{~g} \mathrm{C} \mathrm{m}^{-2}$. This simulated the equivalent enrichment of $\sim 10 \mathrm{~d}$ during a spring bloom period in the Kattegat that has a mean annual production of $144 \mathrm{~g} \mathrm{C} \mathrm{m}^{-2}$ (Rydberg et al. 1990).

The particle-size distributions of both the sediment and phytoplankton particles added were determined. A known weight of sediment was sieved and sorted into size categories. The mass of sediment within each category was converted to sediment volume using a sediment density of $1.7 \mathrm{~g} \mathrm{~cm}^{-3}$. The phytoplankton (Rhodomonas baltica) cells were suspended in $0.9 \mathrm{~g}$ $\mathrm{NaCl} / 1$ solution and measured using a Coulter Multisizer particle counter. Particle-size distributions for both the particle treatments were expressed as \% particle volume within each size category and are graphically represented in Fig. 1. Maximum particle volume was recorded at particle diameters of 125 to 250 and 8 to $9 \mu \mathrm{m}$ for the sediment and phytoplankton treatments, respectively.

Faunal treatments were divided into 2 groups: in the first group the box-cosms retained their faunal component, in the other (control) group, they were defaunated with a $30 \% \mathrm{NaCl}$ solution (Brock 1979). This solution was recirculated at a constant rate throughout the experimental period to the control group box-cosms
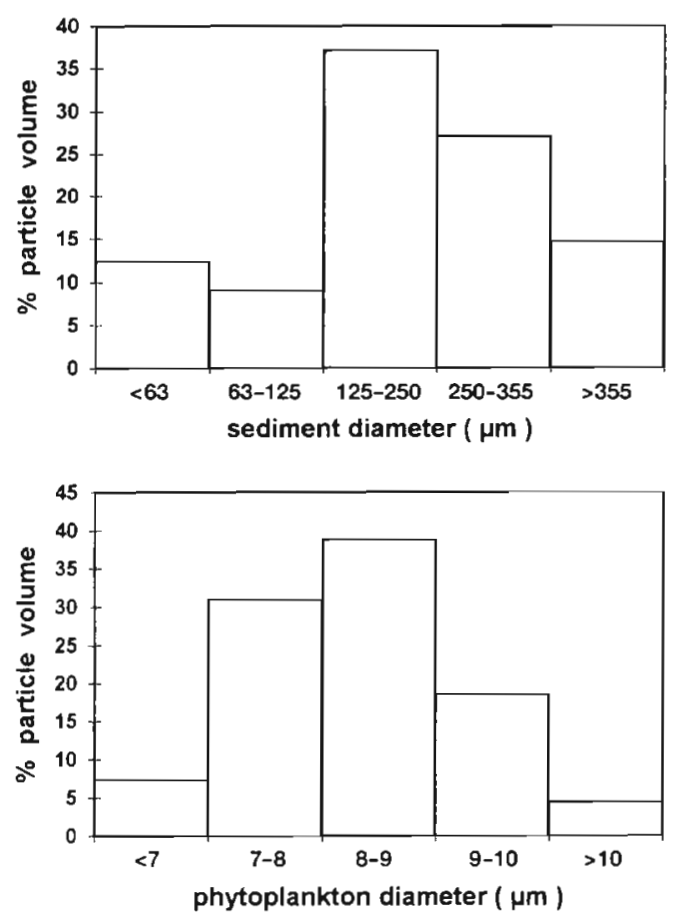

Fig. 1. Particle-size distributions of sediment and phytoplankton particles added to experimental box-cosm system 
to simulate overlying water-flow conditions similar to those in the faunated box-cosms. Replicate core samples were removed from all defaunated control boxcosms after the $48 \mathrm{~d}$ experimental period to ensure that the application of $30 \% \mathrm{NaCl}$ had totally defaunated the sediment. Results showed the absence or death of all macrofaunal and meiofaunal organisms.

All 12 box-cosms received the same pulse addition of ${ }^{51} \mathrm{Cr}$-labelled sediment and phytoplankton particles, which was carefully distributed onto the sediment surface to form a 1 to $2 \mathrm{~mm}$ layer. Radiolabelled ${ }^{14} \mathrm{C}$-DEHP was either associated with the sediment particles $\left(\mathrm{S}_{-D E H P}\right)$ or phytoplankton particles ( $\mathrm{P}_{\text {-DEHP }}$ ), and thus represented the experimental particle treatments. Hence, the experiment consisted of a 2-level factorial design with 4 experimental conditions, as illustrated in Fig. 2. More faunated (4) than defaunated (2) box-cosm replicates were implemented to allow for variations in natural animal communities in faunated sediments. All treatments were randomly assigned.

${ }^{14} \mathrm{C}$ and ${ }^{51} \mathrm{Cr}$ particle labelling. Equal activities of ${ }^{51} \mathrm{CrCl}_{3}\left(47 \mu \mathrm{Ci}^{51} \mathrm{CrCl}_{3}\right.$, Dupont No. NEZ020, chromic chloride in $0.5 \mathrm{M} \mathrm{HCl}$ ) were added to each of 12 flasks containing the sediment mixture. The Rhodomonas baltica stock culture (that would later be divided between the 12 flasks) was dosed with a total of $564 \mu \mathrm{Ci}{ }^{51} \mathrm{CrCl}_{3}$. The sediment flasks and phytoplankton culture were incubated overnight. After $24 \mathrm{~h}$, the flask contents and phytoplankton were rinsed in $0.45 \mu \mathrm{m}$ fresh-filtered seawater and centrifuged at $6500 \mathrm{rpm}$ for $10 \mathrm{~min}$. This rinsing procedure was repeated 5 times. All sediment and phytoplankton particles were thus labelled with ${ }^{51} \mathrm{CrCl}_{3}$, enabling experimental ${ }^{51} \mathrm{Cr}$ values to be used to estimate total mixing.

$215 \mu \mathrm{Ci}{ }^{14} \mathrm{C}$-DEHP (UL-ring, Sigma) was dissolved in acetone to a total volume of $6 \mathrm{ml}$. Of this, $3 \mathrm{ml}$ was added to half the sediment flasks and $3 \mathrm{ml}$ to half the phytoplankton culture, followed by incubation in the

\begin{tabular}{|c|c|c|}
\hline $\begin{array}{l}\text { All box-cosms received } \\
\text { equal } S+P \text { additions } \\
{ }^{14} \mathrm{C} \text {-DEHP sorbed to: }\end{array}$ & FAUNATED & DefaUnATED \\
\hline SEDIMENT & F $\mathbf{S}_{\text {-DEHP }}$ & D $S_{\text {-DEHP }}$ \\
\hline Phytoplankton & F P.DEHP & D P-DEhP \\
\hline
\end{tabular}

Fig. 2. Experimental design with 4 experimental conditions. DEHP is associated with either sediment (S) or phytoplankton (P) particles (indicated by DEHP subscript) in faunated (F) or defaunated (D) box-cosms. All particles added were ${ }^{51} \mathrm{Cr}$-labelled dark on a reciprocating table. After $24 \mathrm{~h}$ the flask contents and phytoplankton culture were rinsed 5 times as for the ${ }^{51} \mathrm{CrCl}_{3}$ labelling.

Equal amounts of Rhodomonas baltica culture were added to the sediment flasks. Combinations of sediment flasks $\left( \pm{ }^{14} \mathrm{C}\right.$-DEHP) and phytoplankton $\left( \pm{ }^{14} \mathrm{C}\right.$-DEHP) resulted in the assigned treatments (Fig. 2). Therefore all box-cosms received a dose of $17.9 \mu \mathrm{Ci}{ }^{14} \mathrm{C}$-DEHP either associated with sediment or phytoplankton particles, representing a total input of $71.6 \mu \mathrm{Ci}^{14} \mathrm{C}$-DEHP $\mathrm{m}^{-2}$.

\section{Sampling of experimental system}

$\mathrm{PO}^{14} \mathrm{C}$ and ${ }^{51} \mathrm{Cr}$ sediment profiles. Initial sediment cores were sampled in triplicate from all boxes on Day 1 and final sediment cores on Day 48. The corers consisted of acrylic cylinders of $8 \mathrm{~cm}$ diam. Each core was sectioned into $0.5 \mathrm{~cm}$ slices in the upper $2 \mathrm{~cm}$, followed by $1 \mathrm{~cm}$ sections to $4 \mathrm{~cm}$ and $2 \mathrm{~cm}$ intervals down to $8 \mathrm{~cm}$. Aluminium sleeves were used to isolate the 3 holes produced from the initial coring procedure, and they remained in situ for the entire experimental period to ensure sediment stability. Sediment porosity was determined for each sediment slice. Porewater was extracted by centrifugation (see following subsection), and sediment samples were freeze-dried.

Known amounts of sediment were transfered to $5 \mathrm{ml}$ gamma vials and measured for ${ }^{51} \mathrm{Cr}$ content (Packard Instruments, Cobra II). For $\mathrm{PO}^{14} \mathrm{C}$ analysis, sediment sub-samples $(\sim 0.2 \mathrm{~g})$ were transferred to $20 \mathrm{ml}$ glass vials and $1 \mathrm{ml}$ of soluene (Packard Inc.) was added. After $24 \mathrm{~h}$, the samples were sonicated for $10 \mathrm{~min}$, $10 \mathrm{ml}$ Insta-gel (Packard Inc.) was added, and they were vortex-mixed. To reduce chemiluminescence, $200 \mu$ glacial acetic acid was added to each sample and incubated in the dark at room temperature $3 \mathrm{~d}$ prior to liquid scintillation counting (Beckman LS 1801 Scintillation Counter). ${ }^{14} \mathrm{C}$ counts were corrected for background and quench. Because ${ }^{51} \mathrm{Cr}$ emissions can interfere with ${ }^{14} \mathrm{C}$ counting, all ${ }^{14} \mathrm{C}$ samples were counted after a minimum of 4 half-lives of ${ }^{51} \mathrm{Cr}\left(t_{0.5}=27.7 \mathrm{~d}\right)$ to minimize any interference. Recounting showed no detectable decrease due to ${ }^{51} \mathrm{Cr}$ decay.

$\mathrm{DO}^{14} \mathrm{C}$ in porewater. Each replicate core section was divided into POC and DOC sub-samples. Porewater (DOC) was extracted by centrifugation $(16100 \times \mathrm{g}$, $15 \mathrm{~min}$ ) immediately following sectioning. This specification for the centrifugation procedure allowed all particles with a radius of $>0.03 \mu \mathrm{m}$ to settle in accordance with Stoke's law. The supernatant porewater was decanted, Insta-gel was added to the $\mathrm{DO}^{14} \mathrm{C}$ fraction, and liquid scintillation was counted.

Animal-community analysis. Triplicate cores of $8 \mathrm{~cm}$ diameter were removed from all box-cosms at the end 
of the experimental period for animal-community analysis. Each core was sieved through a $350 \mu \mathrm{m}$ mesh and preserved in formalin prior to identification. All individual animals were identified and size parameters (lengths, widths) were recorded.

Animal tissue samples. The sea urchin species Echinocardium cordatum was the dominant species in the box-cosm system. Hence, as an important macrofaunal component in the experimental system, individuals were collected at the end of the experimental period from all box-cosms, and transferred to clean sediment for $24 \mathrm{~h}$ in order to defecate all contaminated sediment. Tissues from each individual $E$. cordatum were analysed for ${ }^{14} \mathrm{C}$ activity using the same procedure as for the sediment, and the $\mathrm{PO}^{14} \mathrm{C}$ body burden was recorded. Prior to tissue analysis, size parameters (length, height, width) of individuals were measured, and volumes estimated by approximating the $E$. cordatum to an ellipsoid. This allowed for variability in size between individuals to be considered and $\mathrm{PO}^{14} \mathrm{C}$ body burden to be expressed per volume tissue ( $\left.\mathrm{dpm} \mathrm{cm}^{-3}\right)$.

\section{Modelling and statistical methods}

Biodiffusion $\left(D_{\mathrm{b}}\right)$ modelling using ${ }^{51} \mathrm{Cr}$ tracer. Particle mixing in the box-cosms was estimated using a 1-dimensional transient-state biodiffusion model, with bioturbation expressed independently as the parameter $D_{\mathrm{b}}$ (Berner 1980). Since the addition of labelled organic material to the box-cosms only occurred at the beginning of the experiment as a pulse addition, sedimentation has been ignored as a vertical mass-transfer mechanism, giving:

$$
\frac{\partial C}{\partial t}=D_{\mathrm{b}} \frac{\partial^{2} C}{\partial x^{2}}
$$

where $C={ }^{51} \mathrm{Cr}$ tracer concentration $\left(\mathrm{dpm} \mathrm{g}^{-1}\right), t=$ time, $x=$ depth, and $D_{\mathrm{b}}\left(\mathrm{cm}^{2} \mathrm{yr}^{-1}\right)=$ biodiffusion coefficient (Crank 1975). The decay term in the equation was omitted because ${ }^{51} \mathrm{Cr}$ activity was corrected for decay before data were used in the biodiffusion model. For a non-steady-state system, the model assumes that the tracer exists solely on the sediment surface at time zero $(C=0$ at $x>0$, and $C=\infty$ at $x=0$ ), and that the sediment/water interface is reflective ( $\delta$ as in Eq. 1), i.e. $\frac{\delta C}{\delta x}=0$ at $x=0$ ). The solution to Eq. (1) for the concentration distribution in a semi-infinite cylinder, is given by Crank as:

$$
C(x, t)=\frac{M}{\left(\pi D_{\mathrm{b}} t\right)^{1 / 2}} \exp \left(-x^{2} / 4 D_{\mathrm{b}} t\right)
$$

where the total amount of substance $M$ diffusing in a cylinder of infinite length and unit cross-section is given by:

$$
M=\int_{-\infty}^{\infty} C(x) \mathrm{d} x
$$

${ }^{51} \mathrm{Cr}$ experimental inventory data, triplicate cores per box-cosm, were plotted as ${ }^{51} \mathrm{Cr}$-concentration-depth profiles. It was assumed that the depth-integrated ${ }^{51} \mathrm{Cr}$ (dpm $\mathrm{cm} \mathrm{g}^{-1}$ ) was proportional to the total ${ }^{51} \mathrm{Cr}$ advected in a diffusion-like manner into the sediment core (dpm per core) and this was substituted for $M$ in Eq. (2). The best fit to the ${ }^{5 i} \mathrm{Cr}$ profiles was determined by a nonlinear least-squares curve fitting of Eq. (2), with $D_{\mathrm{b}}$ as the only free parameter.

Biodiffusion coefficients $\left(D_{\mathrm{b}} \mathrm{s}\right)$ for faunated treatments (FS-DEHP and FP-DEHP) were analysed by 2 -way nested ANOVA with replicate box-cosms nested in the DEHP particle-treatment types. Defaunated treatments (DS-DEHP and DP.DEHP) were analysed separately by 2 -way ANOVA as above, since not only were the box-cosm replicates unequal, but variances in mixing rates were heterogeneous between faunated treatment groups. It was important not to lose information on particle-type effects through the over-riding large effects of animals on sediment mixing, which were to be expected. A Kolmogorov-Smirnov test was used to simply compare the distributions of the faunated and defaunated $D_{\mathrm{b}}$ s and determine the magnitude of mixing attributable to animal activity. Regression analysis was used to determine significant relationships between $D_{\mathrm{b}}$ values and the animal-community parameters species number, number of individuals, total community biomass and diversity $\left(H^{\prime}\right)$.

Biodiffusion data ( $D_{\mathrm{b}}$ values) were also analysed by ANCOVA, with urchin (Echinocardium cordatum) abundance as a covariate, to determine the influence of urchins on differences observed in mixing between DEHP particle-type treatments. In addition, regression analysis of all faunated $D_{\mathrm{b}} \mathrm{s}$ (pooled particle-type treatments) and $E$. cordatum densities were examined. $E$. cordatum abundance and $D_{\mathrm{b}}$ rates per individual urchin were also calculated to determine possible density-dependent relationships. The $D_{\mathrm{b}}$ rate in Box-cosm 8, which was faunated but lacked E. cordatum, was used as a baseline $D_{\mathrm{b}}$ rate and was deducted from other faunated $D_{\mathrm{b}}$ values that included urchins. The $D_{\mathrm{b}}$ rates per individual urchin within each box-cosm was simply estimated by dividing this $D_{\mathrm{b}}$ value attributed to urchin-only activity by the correponding number of urchins.

${ }^{14} \mathrm{C}$ and ${ }^{51} \mathrm{Cr}$ depth profiles. The ${ }^{14} \mathrm{C}$-DEHP and ${ }^{51} \mathrm{Cr}$ depth-profile data were analysed using the depthweighted means for the mean profile of each box-cosm (determined from triplicate cores). Depth-weighted means were calculated by multiplying each relative amount in the depth profile with its corresponding depth value, summing this data, and dividing by the number of original data points in the depth profile. The 
number of depth levels for all depth-weighted mean calculations were equal. This gave an estimate of mixing that could be used to compare treatment effects. Depth-weighted means for the ${ }^{14} \mathrm{C}$-DEHP and ${ }^{51} \mathrm{Cr}$ tracers were analysed as response variables in a repeated measures ANOVA design, with particle type $(\mathrm{S}, \mathrm{P})$ and faunal treatments $(\mathrm{D}, \mathrm{F})$ as independent variables.

Depth-weighted means for both tracers $\left({ }^{14} \mathrm{C}\right.$-DEHP and ${ }^{51} \mathrm{Cr}$ ) were further examined for the faunated treatments only. A repeated-measures ANCOVA design analysed the 2 tracers as response variables with particle type as an independent variable. Echinocardium cordatum density was included in this design as a covariate to account for natural urchin differences between box-cosms. When first-order interactions were significant, post hoc comparisons were performed using Duncan's multiple range test.

Benthic community structure. Animal-community parameters of species number, abundance (total numbers of individuals), biomass, diversity $\left(H^{\prime}\right)$ and total number of urchins, were determined for each boxcosm. Total community biomass was estimated using size parameters of individual animals from core samples to determine animal volumes by approximation to geometric shapes, and subsequent weights were calculated (density of $1.1 \mathrm{~g} \mathrm{~cm}^{-3}$ ) to obtain a total community biomass $\left(\mathrm{m}^{-2}\right.$ ) (Sandnes et al. 2000). Diversity estimates were calculated with the Shannon-Wiener index:

$$
H^{\prime}=-\sum_{i=1}^{S}\left(P_{i}\right)\left(\log _{2} P_{i}\right)
$$

where $H^{\prime}=$ index of diversity, $S=$ number of species, and $P_{i}=$ proportion of total sample belonging to the $i$ th species. Differences in these community parameters between $S_{\text {-DEHP }}$ and $P_{\text {-DEHP }}$ treatments were determined by ANOVA. Data for biomass were $\log _{10}$ transformed to correct for heteroscedasticity before ANOVA. Homogeneity of variances for all other parameters, using Cochran's $C$ and Bartlett's $\chi^{2}$ tests $(\alpha=0.05)$ (Underwood 1981), indicated no necessity for data transformation.

Echinocardium cordatum ${ }^{14} \mathrm{C}$-DEHP body burden. The ${ }^{14} \mathrm{C}$ body burden of Echinocardium cordatum was analysed as a function of DEHP particle treatments by ANOVA to determine the relative influence of both particle treatments (FS.DEHP, FP-DEHP) on the ${ }^{14} \mathrm{C}$ body burden. Homogeneity of variances was tested as above, and the results indicated no necessity to transform data prior to analysis. Regression analysis examined possible relationships between the ${ }^{14} \mathrm{C}$ body burden and biodiffusion coefficients $\left(D_{\mathrm{b}}\right)$, to determine if sediment-mixing rates were correlated to bioaccumulation.
Partitioning of $\mathrm{PO}^{14} \mathrm{C}$ and $\mathrm{DO}^{14} \mathrm{C}$. Depth profiles of both $\mathrm{PO}^{14} \mathrm{C}$ and $\mathrm{DO}^{14} \mathrm{C}$ were used to calculate the depth series integrated $-{ }^{14} \mathrm{C}$, and the $\mathrm{PO}^{14} \mathrm{C}: \mathrm{DO}^{14} \mathrm{C}$ ratios were determined for each box-cosm treatment. Ratio data were analysed by ANOVA to test the significance of DEHP particle-treatment effects on possible degradation processes. Homogeneity of variances was tested using Cochran's $C$ and Bartlett's $\chi^{2}$ tests ( $\alpha=0.05$ ), and data were corrected for heteroscedasticity by $\log _{10}$-transformations. Regression analysis was used to determine significant relationships between $\mathrm{PO}^{14} \mathrm{C}: \mathrm{DO}^{14} \mathrm{C}$ ratios and $D_{\mathrm{b}}$ values.

Total particulate ${ }^{14} \mathrm{C}$ loss. Total core ${ }^{14} \mathrm{C}$-DEHP concentrations were calculated by multiplying the ${ }^{14} \mathrm{C}$ DEHP ( $\left.\mathrm{dpm} \mathrm{g}^{-1}\right)$ in each core slice by the corresponding estimated mass of sediment in each slice (sediment density of $1.7 \mathrm{~g} \mathrm{~cm}^{-3}$ ). A 3-factor ANOVA (TYpe III) tested differences in total core ${ }^{14} \mathrm{C}$-DEHP with respect to time (start, end), particle type ( $S_{-D E H P,} P_{-D E H P}$ ), and faunal treatment (D, F).

\section{RESULTS}

\section{Initial sampling (Day 1)}

Core ${ }^{51} \mathrm{Cr}$ analysis for all box-cosms showed that $>85$ $\pm 20 \% \mathrm{SD}$ of the added radiotracer was within the surface $0.5 \mathrm{~cm}$ of the sediment. ANOVA revealed no significant differences in ${ }^{51} \mathrm{Cr}$ below this level between the faunated and defaunated treatments $(p=0.51)$. Less than $0.5 \pm 1.3 \% \mathrm{SD}$ of the total ${ }^{51} \mathrm{Cr}$ addition was detected below $1.25 \mathrm{~cm}$ depth in faunated treatments, and none was present below this depth in defaunated box-cosms.

Core analysis indicated that $>81 \pm 9 \%$ SD ${ }^{14} \mathrm{C}-\mathrm{DEHP}$ was retained in the upper $0.5 \mathrm{~cm}$ of box-cosm sediment. As for the ${ }^{51} \mathrm{Cr}$ radiotracer, ANOVA revealed no significant differences in ${ }^{14} \mathrm{C}$-DEHP below this level between faunated and defaunated treatments $(p=0.72)$. Less than $4 \pm 3 \% \mathrm{SD}$ and $3 \pm 1 \% \mathrm{SD}$ of ${ }^{14} \mathrm{C}-$ DEHP was measured below $1.25 \mathrm{~cm}$ depth in faunated and defaunated treatments, respectively.

\section{Defaunated sediment cores (final sampling, Day 48)}

All defaunated sediment-core samples confirmed the absence or death of all macro- and meiofaunal organisms. Minor mixing events evident in these boxcosms (see following subsection), are attributable to the $\mathrm{NaCl}$ flow across the sediment surface disturbing the sediment/water interface, the passive deposition of tracers down tubes and burrows, and possibly minor coring artifacts. 


\section{Biodiffusion $\left(D_{\mathrm{b}}\right)$ modelling using ${ }^{51} \mathrm{Cr}$ tracer}

Particle mixing $\left(D_{\mathrm{b}}\right)$ as estimated using the Crank model (Eq. 2) fitted the experimental ${ }^{51} \mathrm{Cr}$-profile data very well, with all regression coefficients $>0.922$ (Fig 3). Estimates of mixing from the ${ }^{51} \mathrm{Cr}$ measurements in the box-cosm system are comparable, although generally higher than, the biodiffusion rates found by Wheatcroft et al. (1990), especially in boxcosms with high urchin densities.

ANOVA results of $D_{\mathrm{b}}$ values for the faunated treat-

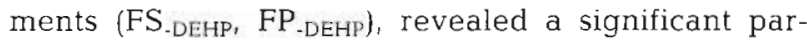
ticle-treatment effect $(p<0.05)$. Duncan's post-hoc analysis revealed that biodiffusion $\left(D_{\mathrm{b}}\right)$ was significantly greater in the box-cosms that received the DEHP contaminant associated with phytoplankton particles $\left(\overline{D_{\mathrm{b}}}=3.3 \pm 1.9\right)$, than those with sedimentassociated DEHP $\left(\overline{D_{\mathrm{b}}}=1.8 \pm 1.5\right)$. ANCOVA (Type III) statistically measured the effect of the 2 different DEHP particle treatments on $D_{\mathrm{b}}$ rates, with Echinocardium cordatum abundance as a covariate. Results showed that these urchins have a highly significant effect $(p<0.01)$ on $D_{b}$ rates, and when this effect is removed from the analysis the influence of particle type is non-significant ( $p=0.17$ ) (Table 1). Therefore, the higher measured $D_{b}$ values in the phytoplankton treatment ( $F P_{-D E H P}$ ) were attributed to an experimental urchin effect, as higher natural densities of $E$. cordatum were present in the $\mathrm{FP}_{\text {aDEHP }}$ than in the FS.DEHP box-cosms (see following subsection). Comparison of ${ }^{14} \mathrm{C}$-DEHP and ${ }^{51} \mathrm{Cr}$ tracer profiles, analysed (following subsection), also showed that particle type (S, P) did not significantly affect tracer distributions

Nested ANOVA for defaunated treatments (DS -DEHP, DP.DEHP), indicated no significant differences in $D_{\mathrm{b}}$ values between particle-type treatments, with mean
A

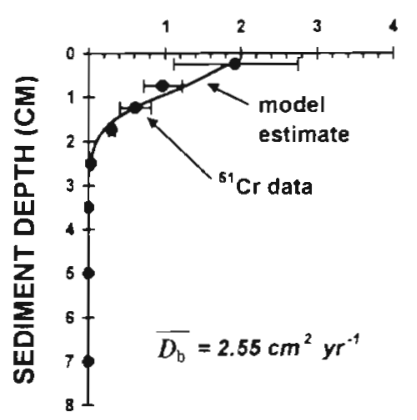

B

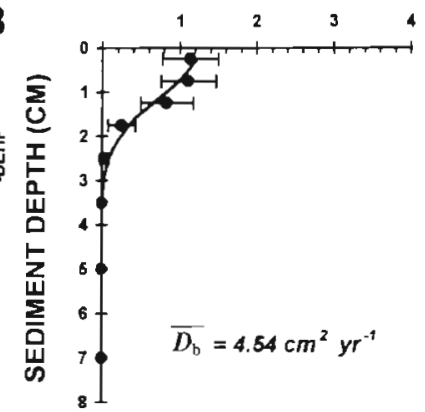

C

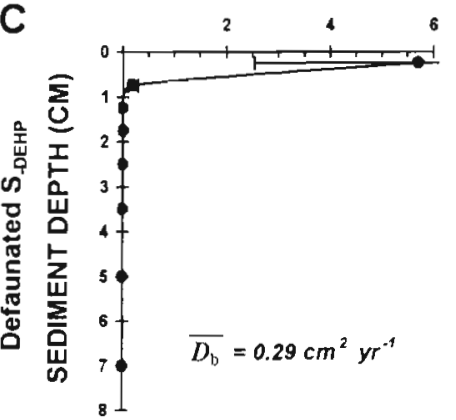

${ }^{51} \mathrm{Cr}$ CONCENTRATION $\left(\times 10^{6} \mathrm{DPM} \mathrm{g}^{-1}\right)$
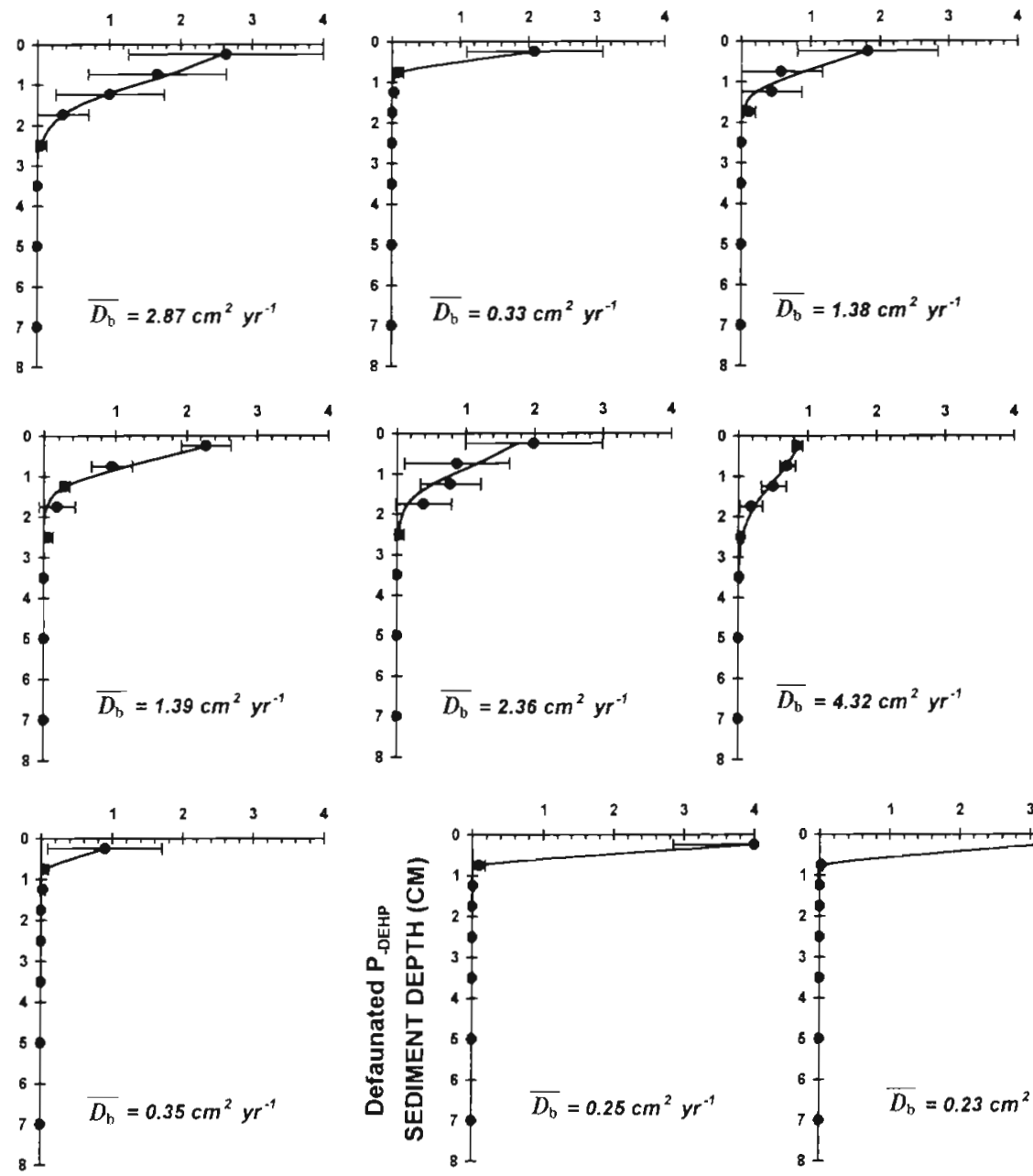

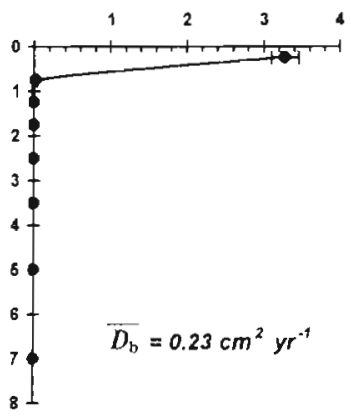

Fig. 3. Depth profiles of absolute ${ }^{51} \mathrm{Cr}$ concentration $\left(\times 10^{6} \mathrm{dpm} \mathrm{g}^{-1}\right) \pm \mathrm{SE}$, with fitted (lines) mean biodiffusion coefficient $\left(D_{b}\right)$ estimates (Eq. 2) for faunated (A,B) and defaunated (C) box-cosm treatments 
Table 1. ANCOVA. (Type III) of effect of particle-type treatments on biodiffusion coefficient $\left(D_{\mathrm{b}}\right)$ rates with urchin density as covariate. Significance levels reflect significant differences within the given factor $(" \mathrm{p}<0.01)$

\begin{tabular}{|lrrrr|}
\hline Source of variation & df & SS & $F$ & $\mathrm{p}$ \\
\hline Main effects (independent variables) & & \\
$\quad$ Particle & 1 & 2.7 & 2.03 & 0.17 \\
$\quad$ Box-cosms & 3 & 9.5 & 2.41 & 0.10 \\
Covariate & & & & \\
$\quad$ Urchin density & 1 & 15.8 & 12.04 & $0.003 \cdots$ \\
Residual & 17 & 22.4 & & \\
\hline
\end{tabular}

values of $0.30 \pm 0.06$ and $0.25 \pm 0.04$ for the sediment (DS.DEHP) and phytoplankton (DP.DEHP) treatments, respectively, and no box-cosm effect. Statistical comparisons of $D_{\mathrm{b}}$ rates in faunated and defaunated treatments showed a 9-fold increase in particle-mixing rates $\left(D_{\mathrm{b}} \mathrm{s}\right)$ attributed to animal presence (Fig. 4$)$.

\section{${ }^{14} \mathrm{C}$ and ${ }^{51} \mathrm{Cr}$ depth profiles}

Relative sediment-depth profiles of ${ }^{14} \mathrm{C}$-DEHP and ${ }^{51} \mathrm{Cr}$ are shown in Fig. 5. All faunated profiles displayed higher relative ${ }^{51} \mathrm{Cr}$ concentrations than ${ }^{14} \mathrm{C}$ DEHP in the upper sediment section(s) (Fig. 5A,B), with a shift at $\sim 1$ to $2 \mathrm{~cm}$ sediment depth in most boxcosms. Tracer data were compared statistically using a depth-weighted means approach. Depth-weighted relative means for both the ${ }^{14} \mathrm{C}-\mathrm{DEHP}$ and ${ }^{51} \mathrm{Cr}$ profiles were calculated for all box-cosms and the mean values for all treatments are represented in Fig. 6.

Repeated-measures ANOVAs of depth-weighted relative means for both tracers $\left({ }^{14} \mathrm{C}\right.$-DEHP and $\left.{ }^{51} \mathrm{Cr}\right)$ revealed a highly significant difference in tracer mixing-depth between the faunal treatments $(D, F)$

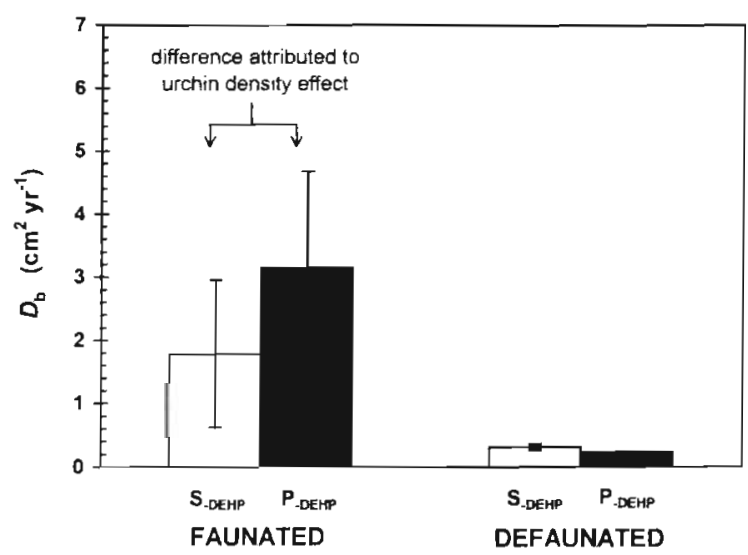

Fig. 4. Mean $D_{\mathrm{b}}$ s estimated from inert ${ }^{51} \mathrm{Cr}$ tracer by Crank model (Eq. 2). Error bars: $\pm \mathrm{SE}$ $(p=0.002)$, with higher depth-weighted means for faunated treatments, as expected. A 2-way interaction effect indicated significant differences in the relationship between tracers for the 2 faunal treatments $(p=0.011)$, and a Duncan's post hoc analysis showed ${ }^{14} \mathrm{C}$-DEHP and ${ }^{51} \mathrm{Cr}$ to be coupled in defaunated box-cosms and decoupled when animals were present (Table 2). This decoupling effect of tracers in faunated box-cosms was independent of particle type $(p=0.90)$. For both particle treatments, higher depth-weighted relative means were measured for ${ }^{14} \mathrm{C}$-DEHP contaminant than for the inert ${ }^{51} \mathrm{Cr}$ tracer. Since tracer profiles are calculated on relative scales, this would indicate either an increase in burial of the ${ }^{14} \mathrm{C}$-DEHP contaminant through faunal activity, or a decrease in surface ${ }^{14} \mathrm{C}$-DEHP through biodegradation.

The mixing of both tracers was independent of particle type $(p=0.52)$. In the faunated box-cosms, both the ${ }^{14} \mathrm{C}$-DEHP and ${ }^{51} \mathrm{Cr}$ tracers showed higher depth-weighted relative means in the the phytoplankton DEHP treatment (FP.DEHP) than in the sediment (FS-DEHP). This mirrors the $D_{\mathrm{b}}$ results, and this effect is attributed to an experimental urchin-effect.

A repeated-measures ANCOVA of depth-weighted relative means for both tracers in faunated sediments incorporated urchin density as a covariate into the statistical design. The results showed no effect of particle type on tracer distributions $(p=0.75)$ and a highly significant decoupling of tracers $\left({ }^{14} \mathrm{C}-\mathrm{DEHP}\right.$ and $\left.{ }^{51} \mathrm{Cr}\right)$ with urchins present $(p=0.003)$ (Table 3$)$.

\section{Benthic community structure}

Table 4 presents an extensive species list for each box-cosm, showing all infaunal species with corresponding abundances. Table 5 presents animal-community parameters (species number, abundance [total numbers of individuals], biomass, diversity $\left[H^{\prime}\right]$ and Echinocardium cordatum density) for all faunated boxcosms. The ANOVA results revealed no significant differences between treatment groups $S_{\text {-DEHP }}$ and $P_{\text {-DEHP }}$ for species number $(p=0.76)$, abundance $(p=0.33)$ or diversity $H^{\prime}(\mathrm{p}=0.80)$. However, community biomass was significantly greater in the $\mathrm{P}_{\text {-DEHP }}$ treatment group than the $S_{\text {-DEHP }}$ group $(p=0.01)$, because of differences in the abundances of $E$. cordatum.

\section{Impact of urchin densities on bioturbation and benthic community structure}

Direct correlation was found between total community biomass and $D_{\mathrm{b}}$ rates $\left({ }^{51} \mathrm{Cr}\right.$ data $)$ evaluated by the Crank model (Fig. 7), verifying the importance of biomass (size) 

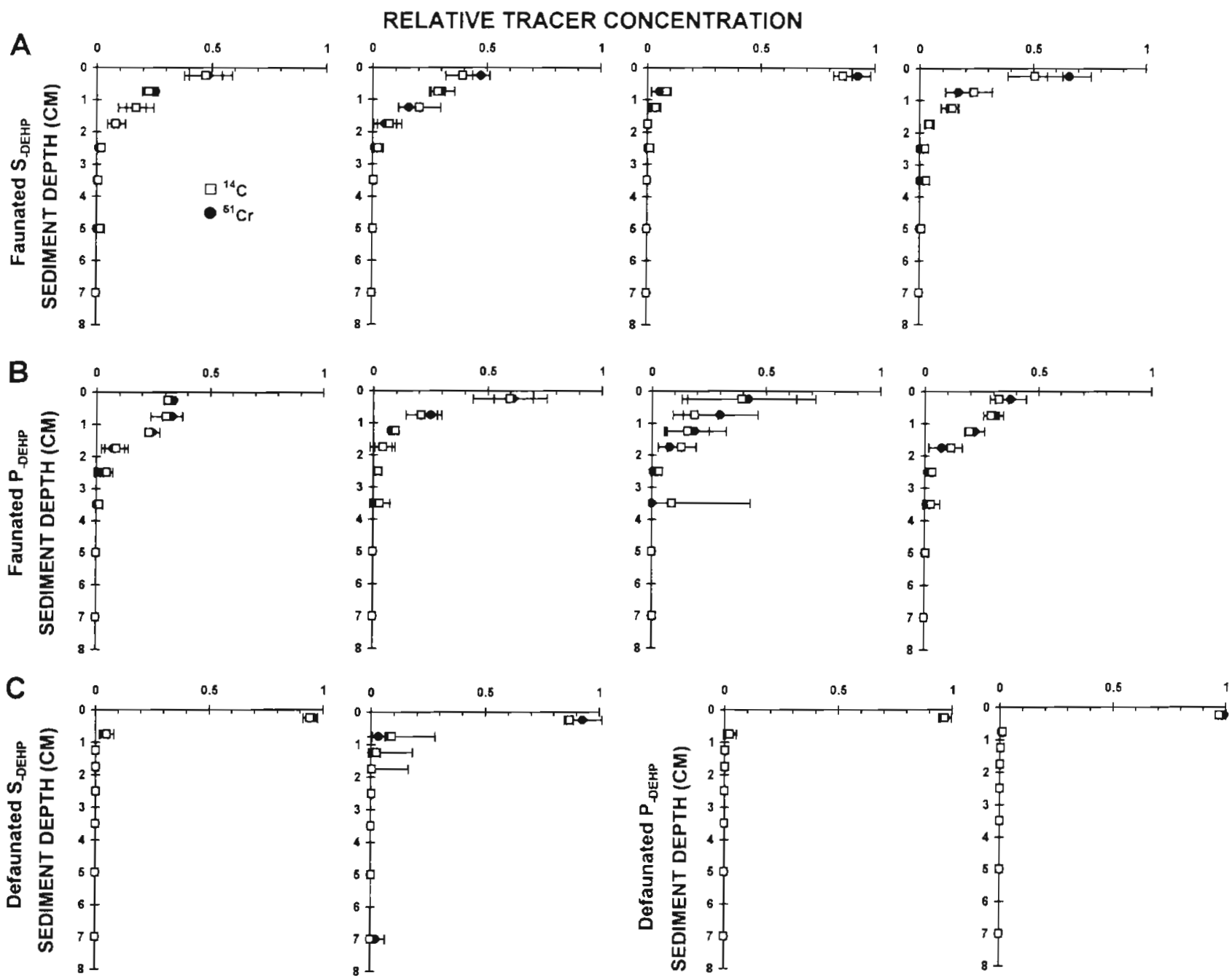

Fig. 5. Relative depth profiles of ${ }^{14} \mathrm{C}(a)$ and ${ }^{5 I} \mathrm{C} r(\bullet) \pm S E$ for faunated $(\mathrm{A}, \mathrm{B})$ and defaunated (C) box-cosm treatments

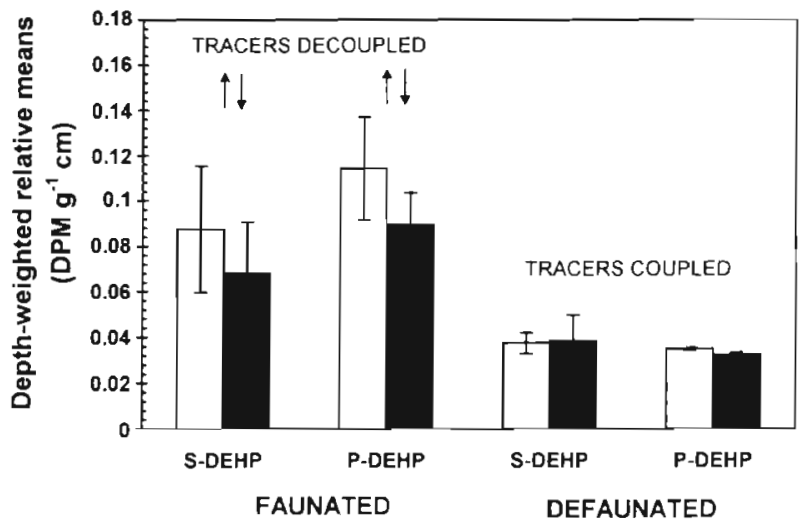

Fig. 6. Depth-weighted relative means of ${ }^{14} \mathrm{C}$ (open) and ${ }^{5 \mathrm{C}} \mathrm{Cr}$ (filled) depth profiles for all treatments. ${ }^{14} \mathrm{C}$ and ${ }^{51} \mathrm{Cr}$ tracers were coupled in defaunated box-cosms and decoupled with animals present. Decoupling of tracers in faunated treatments was independent of particle type. Error bars: $\pm \mathrm{SE}$
Table 2. Repeated-measures ANOVA of depth-weighted means for tracers $\left({ }^{14} \mathrm{C}\right.$-DEHP and $\left.{ }^{51} \mathrm{Cr}\right)$ as response variables, with DEHP particle type $(S, P)$ and faunal treatments $(D, F)$ as independent variables. Significance levels reflect significant differences within the given factor $(" p<0.05 ; " * p<0.01)$

\begin{tabular}{|lrrl|}
\hline Source of variation & MS & $F$ & $\mathrm{p}$ \\
\hline $\begin{array}{l}\text { Main effects } \\
\text { Independent variables }\end{array}$ & & & \\
$\quad$ Particle & 0.0003 & 0.45 & 0.52 \\
$\quad$ Faunal & 0.0143 & 20.12 & 0.002 \\
Response variable & & & \\
$\quad$ Tracers & 0.0006 & 8.86 & $0.018^{\cdot}$ \\
Interactions & & & \\
$\begin{array}{l}\text { Particle } \times \text { Faunal } \\
\text { Particle } \times \text { Tracers }\end{array}$ & 0.0014 & 1.99 & 0.20 \\
$\begin{array}{l}\text { Fauna } \times \text { Tracers } \\
\text { Particle } \times \text { Faunal } \times \text { Tracers }\end{array}$ & 0.0000 & 0.83 & 0.39 \\
& 0.0007 & 10.81 & 0.011. \\
\hline
\end{tabular}


Table 3. Repeated-measures ANCOVA of effect of particletype treatments on tracer depth-weighted, relative means in faunated treatments with urchin density as covariate. Significance levels reflect significant differences within the given factor $(" p<0.01)$

\begin{tabular}{|lccc|}
\hline Source of variation & MS & $F$ & $\mathrm{p}$ \\
\hline $\begin{array}{l}\text { Main effects } \\
\text { Independent variables } \\
\quad \text { Particle }\end{array}$ & $6.6 \times 10^{-5}$ & 0.11 & 0.75 \\
$\begin{array}{l}\text { Response variable } \\
\text { Tracers }\end{array}$ & 0.002 & 23.9 & $0.003 \cdots$ \\
$\begin{array}{l}\text { Interactions } \\
\text { Particle } \times \text { Tracers }\end{array}$ & $3.0 \times 10^{-5}$ & 0.36 & 0.57 \\
\hline
\end{tabular}

in sediment-mixing (Wheatcroft et al. 1990, Sandnes et al. 2000). Results of regression anaiysis showed that the large urchin Echinocardium cordatum dominated the benthic community in terms of size, with total community biomass significantly increasing as a result of increasing urchin density $\left(p<0.001, R^{2}=96 \%\right)$.

Since these large macrofaunal urchins have great impact potential in sediment-mixing, a regression analysis was used to further examine their influences on bioturbation. Fitting a linear model to describe the relationship between $D_{b}$ rates (pooled particle-type treatments) and Echinocardium cordatum density revealed a highly significant positive relationship at the $99 \%$ confidence level ( $p<0.01, R^{2}=75 \%$ ) (Fig. 8A). Differences in observed biodiffusion rates between DEHP particle-treatment groups in this study were thus clearly explained by natural variations in $E$. cordatum densities between faunated treatments.

Fig. $8 \mathrm{~B}$ shows the individual $D_{\mathrm{b}}$ contribution by urchins as a function of urchin density and reveals a trend of higher $D_{b}$ rates by individual urchins within

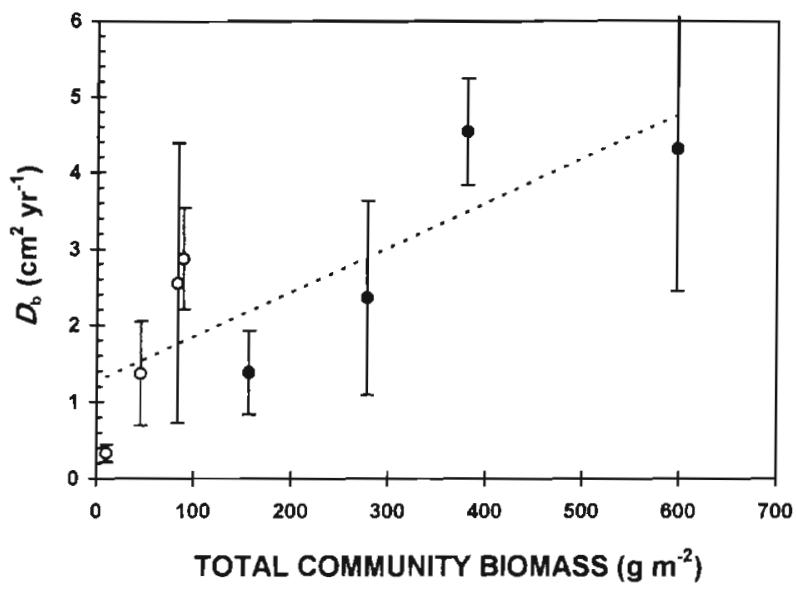

Fig. 7. Regression analysis of $D_{\mathrm{b}}$ values evaluated by Crank model (Eq. 2) and total community biomass for faunated treatments FS.DEHP $(0)$ and FP.DEHP $(\bullet)$. Error bars: \pm 1 SD
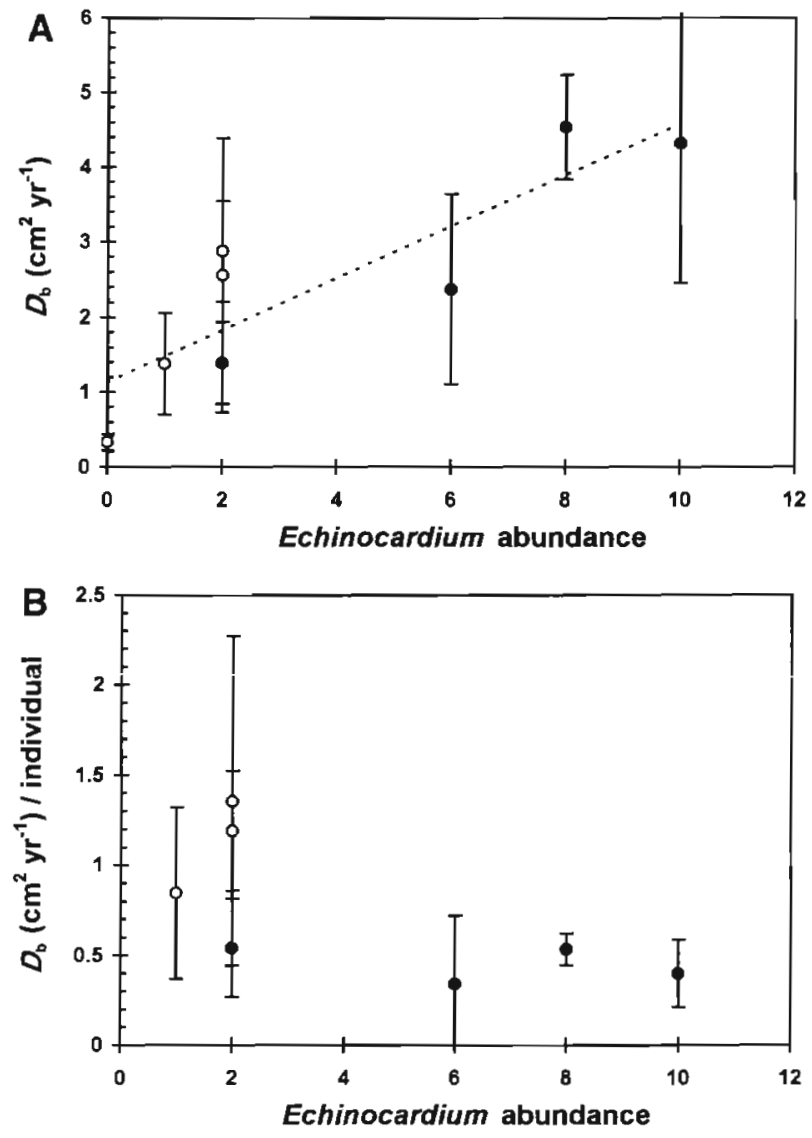

Fig. 8. (A) Regression analysis of $D_{\mathrm{b}}$ evaluated by Crank model (Eq. 2) and dominant species abundance of Echinocardium cordatum in FS DEHP $_{\text {(O) }}$ and FP.DEHP $(\bullet)$; (B) densitydependent relationship between $E$. cordatum abundance and individual $D_{\mathrm{b}}$ rates. Error bars: $\pm 1 \mathrm{SD}$

$\mathrm{FS}_{\text {-DEHP }}$ compared to FP.DEHP treatments. This may indicate a general density-dependent relationship in $D_{\mathrm{b}}$ rates, with a decrease in individual urchin-mixing concurrent with increased population densities. However, since this experimental urchin gradient occurred by chance in the experimental box-cosm system, is not replicated as an experimental factor, and urchin abundances do not overlap, only trends can be suggested.

Echinocardium cordatum densities correlated strongly with the number of other benthic infaunal species present in the box-cosms. Visual inspection of species number along an $E$. cordatum density gradient, revealed maximum species numbers at intermediate E. cordatum densities (Fig. 9). This is in accordance with theories on intermediate disturbance (Connell 1978). A second-order polynomial was fitted to this distribution, and revealed a very strong relationship between species number and $E$. cordatum density $\left(p<0.01, R^{2}=84 \%\right)$. From the fitted curve, a maximum of 34 to 35 species would be expected at field densities of 21 to 22 E. cordatum $\mathrm{m}^{-2}$. 
Table 4. Species abundance. Nos. 1-11 and 3-9: box-cosm nos.; letters A-C: replicates; -: species absent

\begin{tabular}{|c|c|c|c|c|c|c|c|c|c|c|c|c|c|c|c|c|c|c|c|c|c|c|c|c|}
\hline \multirow[t]{3}{*}{ Species } & \multicolumn{12}{|c|}{ Sediment.DEMP } & \multicolumn{12}{|c|}{ Phytoplankton DEHP $_{\text {P }}$} \\
\hline & \multicolumn{3}{|c|}{1} & \multicolumn{3}{|c|}{6} & \multicolumn{3}{|c|}{8} & \multicolumn{3}{|c|}{11} & & 3 & & & 4 & & & 5 & & & 9 & \\
\hline & A & B & $\mathrm{C}$ & A & $\mathrm{B}$ & C & A & $\mathrm{B}$ & C & A & B & $\mathrm{C}$ & A & $\mathrm{B}$ & C & A & B & C & A & B & $\mathrm{C}$ & A 1 & B & $\mathrm{C}$ \\
\hline Abra nitida (Mueller, 1789) & 2 & 1 & 1 & 1 & 1 & - & - & - & - & 2 & - & - & 1 & 1 & 1 & - & 2 & - & - & - & - & 3 & 2 & 5 \\
\hline Amaeana trilobata (M. Sars, 1863) & - & - & - & - & 1 & 2 & - & - & - & - & - & - & - & - & - & - & - & - & - & - & - & - & - & - \\
\hline Anobothrus gracilis (Malmgren, 1865) & - & - & - & 1 & 2 & 2 & - & - & - & 2 & 1 & - & 1 & - & - & - & - & - & - & 1 & - & - & - & 1 \\
\hline Ascidiacea indeterminate & - & 1 & - & - & - & - & - & - & - & - & - & - & - & - & - & - & - & - & - & - & - & - & - & - \\
\hline Brada spp. & - & - & - & - & - & 1 & - & - & - & - & - & - & - & - & - & - & - & - & - & - & - & - & - & - \\
\hline Caulleriella & - & - & 1 & - & 2 & - & - & 1 & - & 2 & - & 2 & - & - & 1 & - & - & 2 & - & 1 & - & - & 3 & 1 \\
\hline Cerianthus Iloydi (Gosse) & - & - & - & - & - & - & - & - & - & - & - & - & - & - & - & - & - & - & 1 & - & - & - & - & - \\
\hline Chaetozone setosa (Malmgren, 1867) & 39 & 18 & 38 & 19 & 21 & 6 & 2 & 1 & 9 & 59 & 8 & 49 & 16 & 19 & 28 & & 612 & 23 & 10 & 171 & 13 & & 376 & 69 \\
\hline $\begin{array}{l}\text { Cossura longocirrata (Webster \& } \\
\text { Benedict, 1887) }\end{array}$ & 17 & 23 & 37 & 12 & 40 & 17 & 6 & 15 & 15 & 90 & 22 & 44 & 65 & 15 & 16 & & 262 & 21 & 4 & 7 & 7 & 922 & & 86 \\
\hline Diplocirrus glaucus (Malmgren, 1867) & - & - & - & 2 & 1 & - & - & - & - & 1 & - & - & 2 & 1 & - & 2 & 1 & 1 & 1 & 1 & - & 1 & 1 & - \\
\hline Echinocardium & & 2 & & & 2 & & & - & & & 1 & & & 8 & & & 2 & & & 6 & & & 10 & \\
\hline Eteone spp. & 6 & 1 & 8 & 2 & 4 & 2 & 1 & 1 & 2 & 1 & - & 5 & 7 & 5 & - & 4 & 6 & 3 & 7 & 6 & 5 & 7 & 3 & 10 \\
\hline Flabelligera affinis (M. Sars, 1 & - & 2 & - & - & - & 1 & - & - & - & - & - & - & - & - & - & - & - & - & - & 1 & 1 & - & - & - \\
\hline Glycera alba & - & 1 & - & - & - & 1 & 1 & - & - & - & - & 1 & 3 & 1 & - & - & - & 1 & - & - & - & - & 1 & - \\
\hline Goni & 1 & - & 1 & - & - & - & - & - & - & - & - & - & - & 1 & - & - & - & - & - & - & - & 2 & - & - \\
\hline $\mathrm{Har}$ & - & - & - & - & - & - & - & - & - & - & - & - & - & - & - & - & - & 1 & - & - & - & - & - & - \\
\hline Hesi & - & 1 & - & - & - & - & - & - & - & - & - & 1 & - & - & - & - & - & - & - & - & 1 & - & - & - \\
\hline Claparède, 1864) & - & - & 4 & - & 1 & - & 3 & - & - & - & - & 2 & - & - & - & - & - & 1 & 2 & 1 & 1 & - & - & - \\
\hline Lumbrin & - & - & - & - & - & - & - & - & - & - & - & - & 1 & 1 & - & - & - & 1 & - & - & - & - & - & - \\
\hline (Gmelin 1790) & - & - & - & - & - & - & - & - & - & - & - & - & - & - & - & - & - & - & - & - & 1 & - & - & - \\
\hline $\mathrm{Mec}$ & - & 10 & 6 & 11 & 12 & 12 & 8 & 4 & 1 & 13 & 5 & 16 & 10 & 8 & 5 & 19 & 19 & 20 & 16 & 18 & 9 & 7 & 6 & 4 \\
\hline $\mathrm{Mel}$ & - & - & - & - & - & - & - & - & - & - & - & - & - & - & - & - & - & - & 1 & - & - & - & - & - \\
\hline & - & - & - & - & - & - & - & - & - & - & - & - & - & - & - & - & - & - & 1 & - & - & - & - & - \\
\hline Mon & - & - & - & - & - & - & - & - & - & - & - & - & - & 1 & - & - & - & - & - & - & 1 & - & - & - \\
\hline Mugga & 1 & - & 1 & - & - & - & - & - & - & 1 & - & - & - & 1 & - & - & - & - & - & - & - & - & - & - \\
\hline My & - & - & - & - & - & - & - & - & - & - & - & - & - & - & - & - & - & - & - & - & - & 1 & - & - \\
\hline My: & - & - & - & - & - & - & - & - & - & - & - & - & - & 1 & - & - & - & - & - & - & - & - & - & - \\
\hline $\mathrm{Ne}$ & - & 3 & 4 & 6 & 12 & 9 & 2 & 5 & 8 & 9 & 1 & 3 & - & 12 & 17 & 2 & 13 & 10 & 1 & 4 & 1 & 4 & 2 & 6 \\
\hline $\mathrm{Ne}$ & - & - & - & 1 & - & - & 3 & - & 4 & 1 & 1 & 1 & - & - & - & 1 & - & - & 3 & - & 2 & - & - & - \\
\hline Nuch & - & - & 1 & - & - & - & - & - & - & - & - & - & - & 1 & - & - & - & - & - & - & - & - & - & - \\
\hline NuC & 1 & 1 & - & - & 1 & 2 & - & 1 & - & 1 & - & - & - & 2 & - & 2 & 1 & - & - & - & 1 & - & - & - \\
\hline Ophelina s & - & 2 & 5 & 4 & 1 & 1 & - & - & - & - & - & - & 1 & 3 & 9 & - & 3 & 2 & 3 & 3 & 4 & 3 & 5 & 5 \\
\hline Oph & 2 & - & 3 & 1 & - & 3 & - & - & 1 & - & - & 2 & 3 & 3 & 3 & - & 4 & - & 1 & - & - & 1 & - & 2 \\
\hline & - & - & - & - & - & - & - & - & - & - & - & - & - & - & - & - & - & - & - & 1 & - & - & - & - \\
\hline Parc & 3 & 6 & 10 & 8 & 2 & 5 & 6 & 8 & 7 & 14 & 7 & 7 & 1 & 2 & 5 & 5 & 3 & 8 & 6 & 8 & 7 & 6 & 6 & 5 \\
\hline Pectinaria auricoma (O.F. Mue & - & - & - & - & - & - & - & - & - & - & - & - & - & - & - & - & - & - & - & 2 & - & - & - & - \\
\hline Pecti & 1 & - & - & 2 & - & - & - & - & - & - & - & 1 & - & - & - & - & - & - & - & - & - & 1 & - & 1 \\
\hline Pholoe & 4 & 4 & 8 & 14 & 14 & 11 & 2 & 1 & 2 & 3 & 1 & 7 & 8 & 6 & 4 & 8 & 7 & 9 & 15 & 7 & 14 & 71 & 10 & 5 \\
\hline$P h y$ & - & - & - & - & - & - & - & - & - & - & - & - & - & - & 1 & - & - & - & - & - & - & - & - & - \\
\hline & - & - & - & - & - & 1 & - & - & - & - & - & - & - & - & 1 & - & - & - & - & - & - & - & - & - \\
\hline Pria & - & - & - & 1 & - & - & - & - & - & - & - & - & - & 2 & - & - & - & - & - & - & - & - & - & - \\
\hline Prionos & 3 & 5 & 2 & 8 & 7 & 6 & - & - & - & 4 & - & 1 & 1 & 8 & 9 & 3 & 5 & 4 & 6 & 5 & 2 & 4 & 8 & 8 \\
\hline Prionospio falla & 1 & - & - & - & - & - & - & - & - & - & - & - & - & - & - & - & - & - & - & 1 & - & - & - & - \\
\hline Prot & - & - & 2 & 2 & - & - & 1 & 1 & - & 5 & - & 1 & 3 & 5 & 1 & - & - & 3 & - & 1 & 2 & 2 & 3 & 2 \\
\hline & 7 & 10 & 9 & 8 & 6 & 13 & - & 2 & 2 & 1 & 3 & 1 & 2 & - & 2 & 8 & 14 & 7 & 16 & 5 & 2 & 2 & - & 4 \\
\hline & - & 1 & 1 & 1 & 2 & - & - & - & - & - & - & - & - & - & - & - & - & - & - & - & - & - & - & - \\
\hline Scoloplos armiger (O.F. Mueller, 1776) & 1 & 1 & - & - & - & - & - & - & - & - & - & - & - & - & 1 & - & - & - & - & - & - & - & - & 1 \\
\hline Spionidae indeterminate & - & - & 1 & - & - & - & - & - & - & - & - & - & - & - & - & - & - & - & - & - & - & - & - & - \\
\hline Spiophane & - & - & - & - & 4 & - & - & - & - & - & - & - & 1 & - & - & - & 1 & - & 5 & 3 & & - & - & - \\
\hline Syl & 1 & - & - & 1 & - & 1 & 3 & - & 1 & 1 & - & - & - & 1 & - & - & 1 & - & - & - & 1 & - & - & - \\
\hline Terebellides stroe & - & - & - & 1 & - & - & - & - & - & - & - & - & - & - & - & - & - & - & - & - & - & - & - & - \\
\hline Thyasira cf. flexuosa (Montagu, 1803) & - & - & - & - & - & - & - & - & - & - & - & 1 & - & - & - & - & - & - & - & - & & - & - & - \\
\hline Thyasira equalis (Verrill \& Bush) & - & - & - & 1 & - & - & - & - & - & - & - & - & - & - & - & - & 2 & - & - & - & & - & - & - \\
\hline Thyasira pygmaea (Verrill \& Bush) & - & - & - & - & - & - & 1 & - & - & - & - & 1 & - & - & - & - & 1 & - & - & - & 1 & - & - & - \\
\hline Thyasira sarsi (Philipp & - & - & - & 1 & 3 & - & - & - & - & - & 1 & - & 2 & - & - & 1 & - & - & - & - & - & - & 1 & - \\
\hline Typosyllis spp. & - & - & - & - & - & - & - & - & - & - & - & - & - & - & - & - & - & - & - & 1 & - & - & - & - \\
\hline
\end{tabular}


Table 5. Animal-community parameters Spp. n: number of species per box; Total abund.: total abundance (mean number per box); Urchin abund.: urchin abundance per box

\begin{tabular}{|c|c|c|c|c|c|}
\hline $\begin{array}{l}\text { Particle treatments } \\
\text { Box-cosm no. }\end{array}$ & $\begin{array}{c}\text { Spp. } \\
n\end{array}$ & $\begin{array}{l}\text { Total } \\
\text { abund. }\end{array}$ & $\begin{array}{l}\text { Biomass } \\
\left(\mathrm{g} \mathrm{m}^{-2}\right)\end{array}$ & $\begin{array}{c}\text { Diversity } \\
\left\{\left(H^{\prime}\right)\right.\end{array}$ & $\begin{array}{l}\text { Urchin } \\
\text { abund. }\end{array}$ \\
\hline \multicolumn{6}{|l|}{ Sediment-DEHP } \\
\hline 1 & 18 & 108 & 83 & 3.14 & 2 \\
\hline 6 & 22 & 114 & 89 & 3.64 & 2 \\
\hline 8 & 12 & 44 & 11 & 3.00 & 0 \\
\hline 11 & 16 & 135 & 46 & 2.60 & 1 \\
\hline \multicolumn{6}{|l|}{ Phytoplankton $_{\text {DEHPP }}$} \\
\hline 3 & 19 & 111 & 381 & 3.24 & 8 \\
\hline 4 & 16 & 138 & 157 & 3.08 & 2 \\
\hline 5 & 20 & 90 & 278 & 3.68 & 6 \\
\hline 9 & 16 & 177 & 598 & 2.69 & 10 \\
\hline
\end{tabular}

Urchin densities were not significantly correlated to total infaunal abundances in the box-cosm system. Some species, however, increased in abundance at intermediate Echinocardium cordatum densities (Mediomastus spp. and Spiophanes kroeyeri), whilst others (Chaetozone setosa) decreased in abundance.

\section{Echinocardium cordatum ${ }^{14} \mathrm{C}-\mathrm{DEHP}$ body burden}

The body sizes of the Echinocardium cordatum from the 2 faunated treatments: FS -DEHP $_{\text {and FP }}$-DEHP $_{\text {showed }}$ no significant differences $(p=0.863)$, with a mean body volume of $5.2( \pm 1.8) \mathrm{cm}^{3}$ and $5.3( \pm 1.7) \mathrm{cm}^{3}$ for

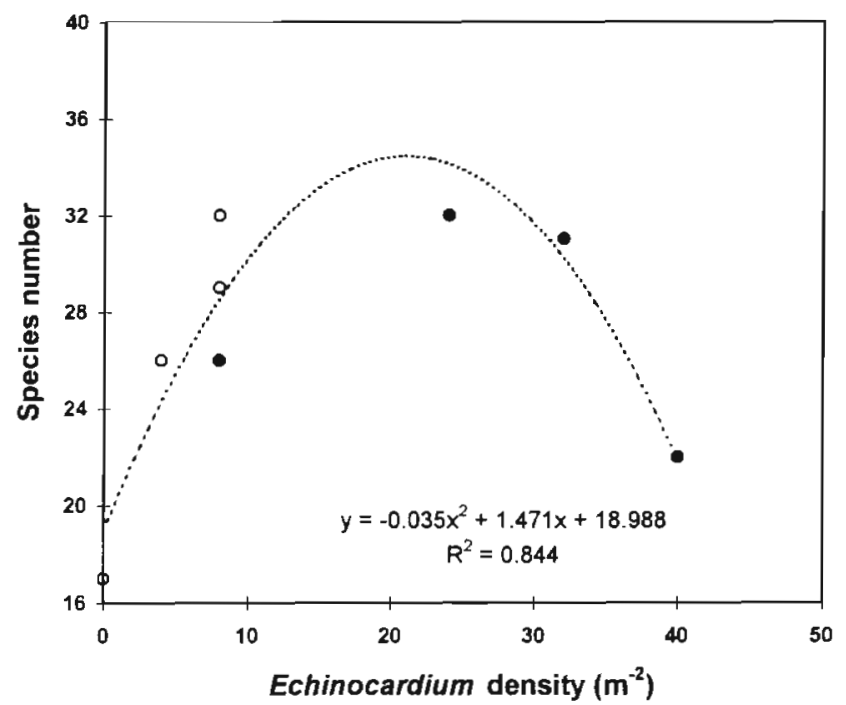

Fig. 9. Species number along Echinocardium cordatum density-gradient in faunated treatments FS.DEHP (o) and $\mathrm{FP}_{\text {.DEHP }}(\bullet)$, showing maximum species number at intermediate urchin densities, as illustrated by fitted second-order polynomial curve fit (dashed line) the 2 DEHP particle-treatment groups, respectively. An ANOVA analysis tested the relative contribution of the 2 particle-type treatments in affecting the ${ }^{14} \mathrm{C}$-DEHP body burden. The results showed that the ${ }^{14} \mathrm{C}$-DEHP body burden was independent of DEHP particle-type $(p=0.912)$. The average ${ }^{14} \mathrm{C}$-DEHP body burden for the FS-DEHP and FP.DEHP treatments were $682( \pm 260) \mathrm{dpm}$ and $711( \pm 114) \mathrm{dpm}$, respectively, as calculated by Fisher's least-significant difference (LSD) multiple-range test. Regression analysis revealed no significant relationship between $E$. cordatum ${ }^{14} \mathrm{C}$-DEHP body burden and biodiffusion coefficients $\left(D_{\mathrm{b}}\right)$.

\section{Partitioning of $\mathrm{PO}^{14} \mathrm{C}$ and $\mathrm{DO}^{14} \mathrm{C}$}

Depth profiles of $\mathrm{DO}^{14} \mathrm{C}$ are represented in Fig. 10 Many of the faunated depth profiles show a subsurface maxima in $\mathrm{DO}^{14} \mathrm{C}$ at 2 to $4 \mathrm{~cm}$. An ANOVA for the depth-integrated $\mathrm{PO}^{14} \mathrm{C}: \mathrm{DO}^{14} \mathrm{C}$ ratios indicated a statistically significant difference between treatments $(p<0.05)$, with significantly higher ratios in both defaunated controls than in faunated treatments (Fig. 11). This can be attributed to lower degradation of $\mathrm{PO}^{14} \mathrm{C}$ to $\mathrm{DO}^{14} \mathrm{C}$ in the absence of fauna irrigating the sediment, as would be expected. Fitting a linear model to describe the relationship between the $\mathrm{PO}^{14} \mathrm{C}: \mathrm{DO}^{14} \mathrm{C}$ ratio and $D_{\mathrm{b}}$ values revealed a marginally significant relationship at the $90 \%$ confidence level $(\mathrm{p}<0.10)$. A correlation coefficient of -0.61 indicated a moderately strong negative relationship between variables, with higher $D_{\mathrm{b}}$ values associated with lower $\mathrm{PO}^{14} \mathrm{C}: \mathrm{DO}^{14} \mathrm{C}$ ratios. Correlations between $\mathrm{PO}^{14} \mathrm{C}: \mathrm{DO}^{14} \mathrm{C}$ ratio and Echinocardium cordatum densities similarly showed a higher ratio at low E. cordatum densities, but this was not statistically significant.

\section{Total particulate $-{ }^{14} \mathrm{C}$ loss}

Results of a 3-factor ANOVA indicated no significant effects of either time (start, end), particle-type ( $S_{\text {-DEHP, }}$ $P$-DEHPl, or faunal treatment (defaunated, faunated) on ${ }^{14} \mathrm{C}$-DEHP total core concentrations $\left(\mathrm{dpm} \mathrm{g}^{-1}\right)$. Therefore, no significant loss or degradation of ${ }^{14} \mathrm{C}$-DEHP was detected in the box-cosm system.

\section{DISCUSSION}

Since organic contaminants associate strongly with sedimenting particles, an understanding of the transport and fate of different particle-types is critical in determining the accumulation and persistence of these 

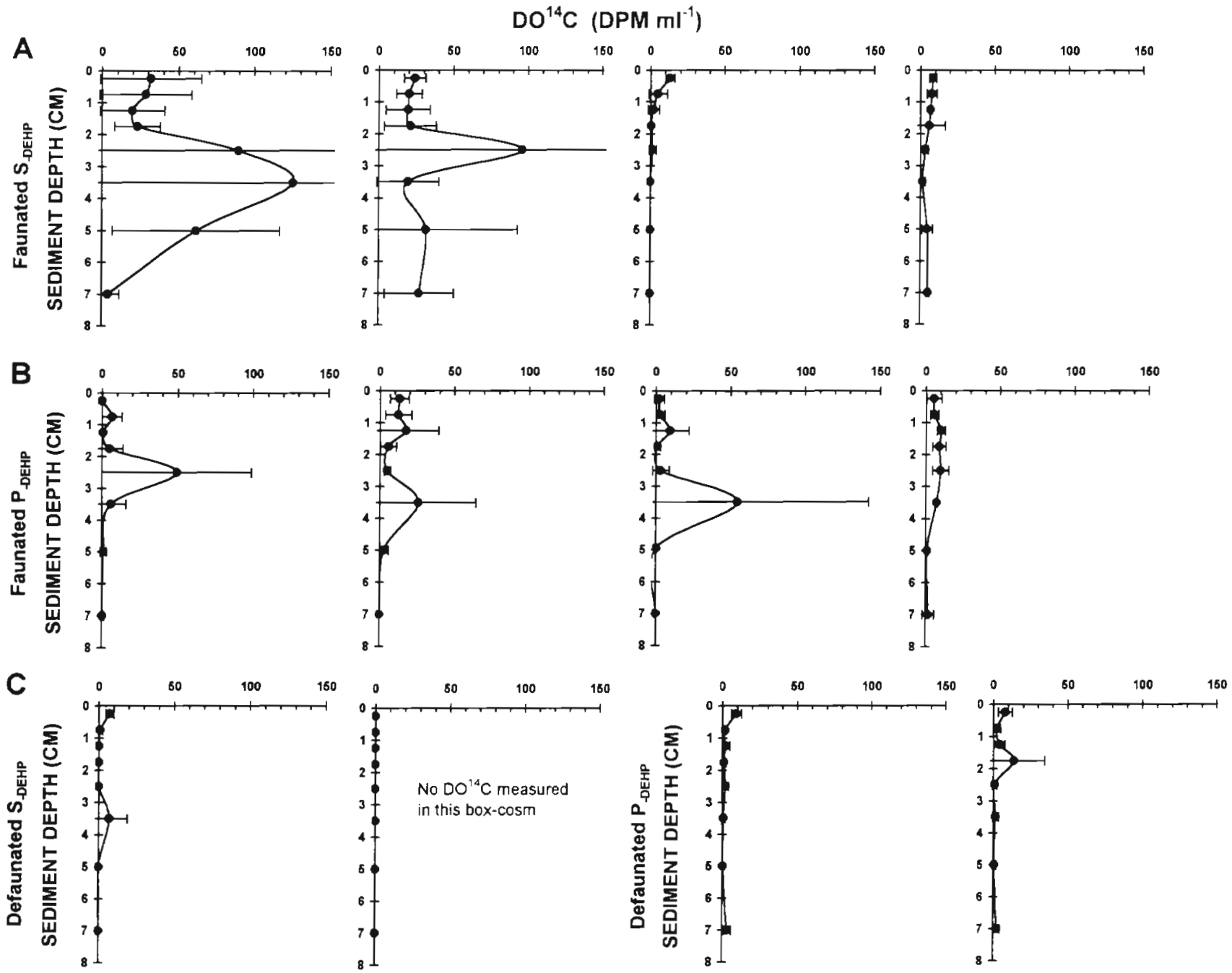

Fig. 10. Depth profiles of $\left.\mathrm{DO}^{14} \mathrm{C}(\mathrm{dpm} \mathrm{ml})^{-1}\right)(\bullet) \pm \mathrm{SE}$ for faunated $(\mathrm{A}, \mathrm{B})$ and defaunated $(\mathrm{C})$ box-cosm treatments

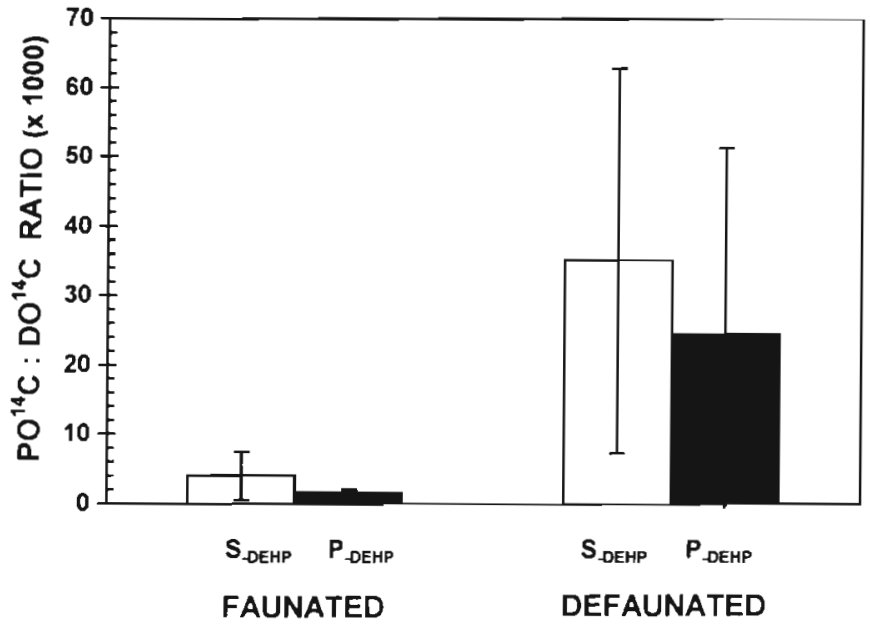

Fig. 11. $\mathrm{PO}^{14} \mathrm{C}: D \mathrm{O}^{14} \mathrm{C}$ ratios of sediment-depth profiles. Error bars: $\pm \mathrm{SE}$ contaminants in marine sediments. This study examined the influence of particle type and faunal activity on the mixing and uptake of the organic contaminant DEHP in natural sediments, using a ${ }^{14} \mathrm{C}-\mathrm{DEHP} /{ }^{51} \mathrm{Cr}$ dual labelling technique (Lopez et al. 1989) adapted for benthic sediment studies by Hansen et al. (1999).

\section{Sediment mixing}

Sediment-mixing rates were represented as $D_{b}$ values resulting from a curve fit of a biodiffusion model (Eq. 2) to the experimental ${ }^{51} \mathrm{Cr}$ depth-profiles. Sediment ${ }^{51} \mathrm{Cr}$ depth-profiles fitted this 1-dimensional, transient-state biodiffusion model well (Fig. 3), as indicated by high correlation coefficients; this validates its use for describing particle-mixing in natural sediments of the Oslofjord. 
Particle-mixing rates were approximately 9-fold higher in faunated than in defaunated control sediments, emphasising and quantifying the importance of macrobenthos as agents of physical transport and biogeochemical catalysis (Aller 1982, Fisher 1982). Comparisons of bioturbation rates between the faunated sediments indicated increased particulate mixing in sediments that received the DEHP contaminant associated with phytoplankton compared to DEHP associated with sediment particles. This was statistically attributed to an experimental urchin-effect, as significantly higher densities of Echinocardium cordatum were recorded in FP.DEHP than in FS -DEHP $_{\text {-Deatments. }}$ Urchin density was a variable that was clearly difficult to control in an experimental system with natural, unmanipulated sediment and faunal communities. Sediment-mixing rates were independent of particle type when this urchin effect was removed.

In this box-cosm study, particles varied in terms of food value and size. The potential food values of the DEHP particle types to the benthos were obviously different in terms of carbon and nitrogen content, with phytoplankton of higher food value to the benthic community. The phytoplankton particles were also smaller than the sediment particles. Our experimental results therefore indicate that neither food value nor size of the particles influenced the sediment-mixing processes and subsequent fate of the DEHP contaminant. This result was unexpected, since the hypothesis of differential reworking of organic-rich particles has been recently presented by a number of investigators (Sun et al. 1991, Smith et al. 1993, Gerino et al. 1998). The idea that fresh particles, with relatively high concentrations of labile organic matter, are more rapidly mixed is compelling (Gerino et al. 1998), because of the biological origin of bioturbation and the known tendency of benthic organisms to preferentially ingest particles rich in organic matter (Lopez \& Levinton 1987). Rapid reworking of fresh particulate matter has also been suggested by Sun et al. (1991) and Smith et al. (1993). Smith et al. concluded that 'food-rich' particles are ingested and mixed at higher rates by depositfeeders than older, 'food-poor' particles. Although, in a recent experimental study by Gerino et al. (1998) that quantified bioturbation rates, results suggested that 'taken at face value, fresh particulate organic matter, as reflected by chlorophyll $a$, tends to be mixed at a rate roughly similar ( $<2$ to $3 \times$ ) to that of bulk sediment'. This is in accordance with the results of the present study.

Sediment-mixing in our box-cosm system also appeared to be independent of particle size. Particle sizedependent mixing has however been well documented by Wheatcroft \& Jumars (1987) and Wheatcroft (1992), with evidence of increased mixing intensity with de- creased particle diameter. However, these studies involved experimentation in a different marine environment (deep-sea basins of $\sim 1200 \mathrm{~m}$ depth) and were conducted over a much longer time scale $(\sim 1000 \mathrm{~d})$ than our study of $48 \mathrm{~d}$.

Before refuting the idea of differential mixing caution is advised, for the following additional reasons. Smallscale mixing processes in our box-cosm study were possibly difficult to detect with the over riding effects of the large macrofauna, Echinocardium cordatum, dominating bioturbation. It is also difficult to compare results directly to other natural bioturbation studies because of the large variation in natural animal communities, with different animal densities, feeding strategies and turnover rates. The addition of phytoplankton particles to our experimental system did not attempt to simulate the association of microbial biomass that occurs during natural phytoplankton particle deposition. This microbial association is an important factor in particle selectivity in deposit-feeders (Smith et al. 1993). Phytoplankton particle-treatment levels in this study were related to realistic spring bloom periods in the Kattegat. However, it is possible that differential reworking of particle types may only be detected in areas experiencing even higher levels of organic enrichment during bloom periods.

\section{${ }^{14} \mathrm{C}$ and ${ }^{51} \mathrm{Cr}$ depth profiles}

The transport and fate of contaminated particles was assessed by comparison of ${ }^{14} \mathrm{C}$-DEHP and ${ }^{51} \mathrm{Cr}$ depth profiles. The results showed the 2 radiotracers to be coupled in defaunated sediments (DS-DEHP, DP.DEHP) and decoupled with animals present (FS-DEHP, FP.DEHP). This effect was independent of particle type. In defaunated sediments, both tracers remained concentrated on the sediment surface, and the ${ }^{14} \mathrm{C}$-DEHP depth profiles were not significantly different from the inert tracer. A decoupling of tracers was detected in faunated sediments, with higher depth-weighted means measured for ${ }^{14} \mathrm{C}$-DEHP than for the inert tracer ${ }^{51} \mathrm{Cr}$. The experimental results are inconclusive regarding mechanisms responsible for this decoupling, but one possible explanation may be microbial degradation of surface ${ }^{14} \mathrm{C}$-DEHP. This is supported by lower $\mathrm{PO}^{14} \mathrm{C}: \mathrm{DO}^{14} \mathrm{C}$ ratios in faunated compared to defaunated treatments, although the total ${ }^{14} \mathrm{C}$-DEHP data showed no significant detectable loss during the experimental period. Microbial degradation of ${ }^{14} \mathrm{C}$-DEHP labelled sediment was also observed by Hansen et al. (1999) in a recent microcosm study, where the presence of Capitella sp. I worms resulted in a 2 -fold increase in mineralization rates. This was attributed to increased microbial respiration stimulated by bioturbatory activities. 


\section{Bioturbation and the benthic community}

As illustrated by the sediment-mixing results, the infaunal community has a major influence on sedimentmixing processes. Total community biomass was shown to correlate strongly with bioturbation, suggesting that size may be the single most important community parameter determining sediment-mixing intensity (Wheatcroft et al. 1990, Sandnes et al. 2000).

Sediment-mixing rates $\left(D_{\mathrm{b}}\right)$ were significantly correlated to Echinocardium cordatum abundance, indicating a particle-transport mechanism directly related to the dominant species in the community in terms of size. Downward particle transport was strongly correlated with urchin abundance, and was independent of DEHP particle-type treatment. A decrease in individual urchin-mixing paralleled increased population densities, i.e. there was a density-dependent relationship. This suggests that increased population sizes subjected the urchins to competitive pressures.

The urchin Echinocardium cordatum is a large deposit-feeder that commonly burrows in deep sediment at the level of the oxidised-reduced interface (Temara et al. 1991). It is protected from this toxic-sulphide rich habitat by water that circulates through its burrow. E. cordatum ingests both surface sediment, via a vertical tube that connects the burrow to the surface, and also deep-seated sediment in bulk. This deep sediment, although depleted in labile organic matter, is thought to play a mechanical role in the digestive process (de Ridder et al. 1985). Observations of the present study showed that during short periods of reduced oxygen supply (during transfer of box-cosms from the boat before addition of treatments), E. cordatum emerged from the deep sediment to the surface. Movement and feeding activities on the surface sediment resulted in very distinct trails, as if 'bulldozing' the sediment. This confirmed their potential for sediment disturbance.

Echinocardium cordatum has major effects on the structure and functioning of an ecosystem. In our experimental system, mixing rates increased from $0.332 \mathrm{~cm}^{2} \mathrm{yr}^{-1}$ in the absence of E. Cordatum (Box$\operatorname{cosm} 8$ ) to a minimum of $1.375 \mathrm{~cm}^{2} \mathrm{yr}^{-1}$ with E. cordatum present in the community, thereby indicating that E. cordatum has a clearly defined and measurable impact on sediment disturbance. By dramatically increasing biodiffusion, these large, bottom-dwelling invertebrates play a key role in habitat modification, modifications that affect vertical chemical gradients, organic matter degradation, microbial activity, chemical pore-water composition and the bioavailability of sedimentary contaminants. In an organic enrichment study by Osinga et al. (1995), aerobic bacterial metabolism was stimulated by E. cordatum as a result of increased oxygen transport to deeper sediment.
Since urchins dominated sediment-mixing processes, changes in faunal community parameters, i.e. species number and total infaunal abundance, were examined along an experimental gradient of urchin density. Maximum of species numbers occurred at intermediate Echinocardium cordatum densities, with a maximum number of 34 to 35 species expected at field densities of 21 to $22 \mathrm{E}$. cordatum $\mathrm{m}^{-2}$. These results are in accordance with a study on the urchin Brissopsis lyrifera by Widdicombe \& Austen (1998) in Norway. Experimental manipulation of urchin densities in their study, showed that density treatments of 28 ind. $\mathrm{m}^{-2}$ resulted in a higher number of infaunal species than heavily disturbed sediments ( 71 ind. $\mathrm{m}^{-2}$ ), where competitive exclusion occurred. This relationship between urchin density and species numbers is consistent with predictions of the intermediate disturbance hypothesis (Connell 1978). At low disturbance rates, dominant species exclude poorer competitors, resulting in low species diversity; at high disturbance rates, diversity is reduced as species are unable to recover from the disturbance effects.

Simple correlations between infaunal abundance and mixing rates/urchin densities did not exist over the relatively restricted numerical ranges. An explanation for this lack of correlation between variables may be related to the disproportionate influences on mixing by different species (Rhoads 1974, Jumars \& Wheatcroft 1989).

\section{Bioavailability of ${ }^{14} \mathrm{C}$-DEHP to Echinocardium cordatum}

The ingestion of contaminated sediment forms an important exposure route of sediment-bound contaminants to deposit-feeding fauna (Landrum \& Robbins 1990, Boese et al. 1990, Harkey et al. 1994, Maloney 1996, Forbes 1999). The bioavailability of organic contaminants such as DEHP is therefore a function of not only its total concentration but also of both the physical and chemical characteristics of the sediment particles that affect faunal ingestion-selectivity (Kukkonen \& Landrum 1995). The ${ }^{14} \mathrm{C}$-DEHP bioaccumulation data on Echinocardium cordatum showed no significant effect of ${ }^{14} \mathrm{C}$-DEHP particle-type on either body sizes of individuals or ${ }^{14} \mathrm{C}$-DEHP body burden, despite a difference in mixing rates between treatments.

\section{CONCLUSIONS}

Sediment mixing of the DEHP contaminant was independent of particle type, as was the decoupling of the ${ }^{14} \mathrm{C}$-DEHP and ${ }^{51} \mathrm{Cr}$ tracers in faunated sediments, indi- 
cating the lack or non-detection of selective transport between the DEHP particle-type treatments in this study. There were consistently higher depth-weighted means for ${ }^{14} \mathrm{C}$-DEHP than for ${ }^{51} \mathrm{Cr}$, and although the experimental results were inconclusive regarding the mechanisms responsible for this decoupling effect, the most likely explanation is a decrease in surface contaminant levels through microbial degradation. Sedimentmixing rates correlated strongly with total community biomass, suggesting that size (biomass) may be the single most important community parameter determining sediment-mixing intensity (Wheatcroft et al. 1990, Sandnes et al. 2000). Downward particle transport was strongly correlated to Echinocardium cordatum abundance $(p<0.01)_{\text {; this }}$ urchin is the dominant species in the benthic community in terms of size. These urchins clearly dominated sediment mixing and did so in a 'non-selective' manner.

Acknowledgements. This study was financially supported by The European Commission as part of a post-doctoral TMR Marie Curie Research Training Fellowship (ERBFMBICT950496) awarded to J.S. Animal identification was undertaken at NIVA and financially supported by the State Pollution Authority (SFT). We are grateful to Jørgen Noerrevang Jensen, who provided invaluable technical assistance, and to Torsten Källqvist for expert advice and assistance with the phytoplankton culture. Our thanks are extended to NIVA (Norwegian Institute for Water Research) for providing facilities at Solbergstrand Marine Station, Oslofjord, and NERI (National Environmental Research Institute), Denmark, for providing additional laboratory facilities.

\section{LITERATURE CITED}

Aller RC (1982) The effects of macrobenthos on chemical properties of marine sediment and overlying water. In: McCall PL, Tevesz MJS (eds) Animal-sediment relations: the biogenic alteration of sediments, 2nd Vol. Topics in geobiology. Plenum Press, New York, p 53-102

Al-Oman LA, Preston MR (1987) The interactions of phalate esters with suspended particulate material in fresh and marine waters. Envir Pollut 46:177-186

Bauer J, Kerr R, Bautista MF, Decker CJ, Capone DG (1988) Stimulation of microbial activities and aromatic hydrocarbon degradation in marine sediments inhabited by Capitella capitata. Mar Environ Res 25:63-84

Berner RA (1980) Early diagenesis: a theoretical approach. Princeton University Press, Princeton, NJ

Boese BL, Lee H II, Specht DT, Randall RC, Winsor MH (1990) Comparison of aqueous and solid-phase uptake for hexachlorobenzene in the tellinid clam Macoma nasuta (Conrad): a mass balance approach. Environ Toxicol Chem 9:221-231

Boudreau BP (1986) Mathematics of tracer mixing in sediments. I. Spatially-dependent, diffusive mixing. II. non local mixing and biological conveyor-belt phenomena. Am J Sci 286:161-238

Brock TD (1979) Ecology of saline lakes. In: Shilo M (ed) Strategies of microbial life in extreme environments. Springer-Verlag, Berlin, p 29-47 (Dahlem Konferenzen)

Calow P, Fletcher CR (1972) A new radiotracer technique involving ${ }^{14} \mathrm{C}$ and ${ }^{51} \mathrm{Cr}$ for estimating the assimilation efficiencies of aquatic, primary consumers. Oecologia 9: $155-170$

Cammen LM (1989) The relationship between ingestion rate of deposit feeders and sediment nutritional value. In: Lopez G, Taghon G, Levinton J (eds) Ecology of marine deposit feeders. Springer-Verlag, New York, p 201-222

Connell JH (1978) Diversity in tropical rain forests and coral reefs. Science (NY) 199:1302-1309

Crank J (1975) Methods of solution when the diffusion coefficient is constant. In: The mathematics of diffusion. Clarendon Press, Oxford, p 11-27

de Ridder C, Jangoux M, De Vos L (1985) Description and significance of a peculiar intradigestive symbiosis between bacteria and a deposit feeding echinoid. J Exp Mar Biol Ecol 96:65-75

de Witt TH, Ozretich RJ, Swartz RC, Lamberson JO, Schults DW, Ditsworth GR, Jones JKP, Hosellon L, Smith LM (1992) The influence of organic matter quality on the toxicity and partitioning of sediment-associated fluoranthene. Environ Toxicol Chem 11:197-208

Fisher JB (1982) Effects of macrobenthos on the chemical properties of freshwater sediments. In: McCall PL, Tevesz MJS (eds) Animal-sediment relations. Plenum Press, New York, p 117-220

Forbes TL (1999) Understanding small-scale processes controlling the bioavailability of organic contaminants to deposit-feeding benthos. In: Gray JS et al. (eds) Biogeochemical cycling and sediment ecology. Kluwer Academic Publishers, Dordrecht, p 125-136

Forbes VE, Forbes TL (1994) Ecotoxicology in theory and practice. Chapman \& Hall, London

Gerino M, Aller RC, Lee C, Cochran JK, Aller Y, Green MA, Hirschberg D (1998) Comparison of different tracers and methods used to quantify bioturbation during a spring bloom: 234-thorium, luminophores and chlorophyll a. Estuar Coast Shelf Sci 46:531-547

Hansen R, Forbes TL, Westermann P (1999) Importance of bioturbation and feeding by the polychaete Capitella species I in the degradation of di(2-ethylhexyl)phthalate (DEHP). Mar Ecol Prog Ser 182:187-199

Harkey GA, Lydy MJ, Kukkonen J, Landrum PF (1994) Feeding selectivity and assimilation of PAH and PCB in Diporeia spp. Environ Toxic Chem 13:1445-1455

Hedges JI, Stern JH (1984) Carbon and nitrogen determinations of carbonate-containing solids. Limnol Oceanogr 29(3):657-663

Jobling S, Reynolds $T$, White R, Parker MG, Sumpter JP (1995) A variety of environmentally persistent chemicals, including some phthalate plasticizers are weakly estrogenic. Environ Health Perspect 103:582-587

Jonasdóttir SH (1994) Effects of food quality on the reproductive success of Acartia tonsa and Acartia hudsonica: laboratory observations. Mar Biol 121:67-81

Jumars PA, Wheatcroft RA (1989) Responses of benthos to changing food quantity and quality, with focuses on deposit feeding and bioturbation. In: Berger WH et al. (eds) Productivity of the ocean: present and past. J Wiley \& Sons, London p 235-254

Karickoff SW, Morris KR (1985) Sorption dynamics of hydrophobic pollutants in sediment suspensions. Environ Toxicol Chem 4:469-479

Kofoed LP (1989) Time-dependent absorption in deposit feeders. In: Lopez G et al. (eds) Ecology of Maine deposit feeders. Spinger-Verlag, New York, p 129-148

Kohli J, Ryan JF, Afghan BK (1989) Phthalate esters in the aquatic environment. In: Afghan BK, Chau ASY (eds) Ana- 
lysis of trace organics in the aquatic environment. CRC Press, Boca Raton, FL, p 243-281

Kukkonen J, Landrum PF (1995) Effects of sediment-bound polydimethylsiloxane on the bioavailability and distribution of benzo(a) pyrene in lake sediment to Lumbriculus variegatus. Environ Toxicol Chem 14(3):523-531

Landrum PF, Robbins JA (1990) Bioavailability of sedimentassociated contaminants to benthic invertebrates. In: Bando R, Giesy JP, Muntau H (eds) Sediments; chemistry and toxicology of in-place pollutants. Lewis Publishers, Ann Arbor, MI, p 237-263

Lopez G, Elmgren R (1989) Feeding depths and organic absorption for the deposit-feeding benthic amphipods Pontoporeia affinis and Pontoporeia femorata. Limnol Oceanogr 34(6):982-991

Lopez GR, Levinton JS (1987) Ecology of deposit-feeding animals in marine sediments. Q Rev Biol 62:235-260

Lopez G, Tantichodok P, Cheng IJ (1989) Radiotracer methods for determining utilization of sedimentary organic matter by deposit feeders. In: Lopez $G$, Taghon $G$, Levinton J (eds) Ecology of marine deposit feeders. SpringerVerlag, New York, p 149-170

Madsen SD, Forbes TL, Forbes V (1997) Particle mixing by the polychaete Capitella species. 1. Coupling fate and effect of a particle-bound organic contaminant (fluoranthene) in marine sediment. Mar Ecol Prog Ser 147:129-142

Maloney J (1996) Influence of organic enrichment on the partitioning and bioavailability of cadmium in a microcosm study. Mar Ecol Prog Ser 144:147-161

Osinga $R$, Lewis WE, Wopereis JLM, Vriezen C, van Duyl FC (1995) effects of the sea urchin Echinocardium cordatum on oxygen uptake and sulfate reduction in experimental benthic systems under increasing organic loading. Ophelia 41:221-236

Powell EN (1977) Particle size selection and sediment reworking in a funnel feeder, Leptosynapta tenuis (Holothuroidea, Synaptidae). Int Rev Ges Hydrobiol 62:385-408

Rhoads DC (1974) Organism-sediment relations on the muddy sea floor. Ocean Mar Biol Annu Rev 12:263-300

Rice DL, Rhoads DC (1989) Early diagenesis of organic matter and the nutritional value of sediment. In: Lopez $G$, Taghon G, Levinton $J$ (eds) Ecology of marine deposit feeders. Springer-Verlag, New York, p 59-97

Riisgård HU (1991) Suspension feeding in the polychaete Nereis diversicolor. Mar Ecol Prog Ser 70:29-37

Rydberg L, Edler L, Floderus S, Granéli W (1990) Interaction between supply of nutrients, primary production, sedimentation and oxygen consumption in SE Kattegat. Ambio 19:134-141

Sandnes J, Forbes T, Hansen R, Sandnes B, Rygg B (2000) Bio-

Editorial responsibility: Otto Kinne (Editor),

Oldendorf/Luhe, Germany turbation and irrigation in natural sediments, described by animal-community parameters. Mar Ecol Prog Ser 197: $169-179$

Smith CR, Pope RH, DeMaster DJ, Magaard L (1993) Agedependent mixing of deep-sea sediments. Geochim Cosmochim Acta 57:1473-1488

Soetaert K, Herman PMJ, Middelburg JJ, Heip C (1998) Assessing organic matter mineralization, degradability and mixing rate in an ocean margin sediment (Northeast Atlantic) by diagenetic modeling. J Mar Res 56:519-534

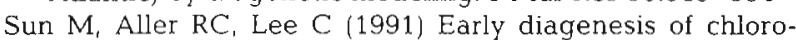
phyll-a in Long Island Sound sediments: a measure of carbon flux and particle reworking. J Mar Res 49:379-401

Temara A, De Ridder C Kaisin $M$ (1991) Presence of an essential polyunsaturated fatty acid in intradigestive bacterial symbionts of a deposit-feeder echinoid (Echinodermata). Comp Biochem Physiol 100B(3):503-505

Thayer CW (1983) Sediment-mediated biological disturbance and the evolution of marine benthos. In: Tevesz MJS, McCall PL (eds) Biotic interactions in recent and fossil communities. Plenum Press, New York, p 479-625

Underwood AJ (1981) Techniques of analysis of variance in experimental marine biology and ecology. Mar Biol Annu Rev 19:513-605

Wams TJ (1987) Diethylhexylphthalate as an environmental contaminant-a review. Sci Total Environ 66:1-16

Wheatcroft RA (1992) Experimental tests for particle size dependent bioturbation in the deep ocean. Limnol Oceanogr 37:90-104

Wheatcroft RA, Jumars PA (1987) Statistical reanalysis for size dependence in deep-sea mixing. Mar Geol 77:157-763

Wheatcroft RA, Jumars PA, Smith CR, Nowell ARM (1990) A mechanistic view of the particulate diffusion coefficient: step length, rest periods and transport directions. J Mar Res 48:177-207

Wheatcroft RA, Olmez l, Pink FX (1994) Particle bioturbation in Massachusetts Bay: preliminary results using a new deliberate tracer technique. J Mar Res 52:1129-1150

Whitlatch RB (1974) Food resource partitioning in the depositfeeding polychaete Pectinaria gouldii. Biol Bull Mar Biol Lab, Woods Hole 147:27-235

Widdicombe S, Austen MC (1998) Experimental evidence for the role of Brissopsis lyrifera (Forbes, 1841) as a critical species in the maintenance of benthic diversity and the modification of sediment chemistry. $J$ Exp Mar Biol Ecol 228:241-255

Williams MD, Adams WJ, Parkerton TF, Biddinger GR, Robillard KA (1995) Sediment sorption coefficient measurement for four phthalate esters: experimental results and model theory. Environ Toxicol Chem 14:1477-1486

Submitted: February 20, 1998; Accepted: October 26, 1999 Proofs received from author(s): March 30, 2000 